\title{
Intercontinental trans-boundary contributions to ozone-induced crop yield losses in the Northern Hemisphere
}

\author{
M. J. Hollaway ${ }^{1}$, S. R. Arnold ${ }^{1}$, A. J. Challinor ${ }^{1}$, and L. D. Emberson ${ }^{2}$ \\ ${ }^{1}$ Institute for Climate and Atmospheric Science, School of Earth and Environment, University of Leeds, Leeds, UK \\ ${ }^{2}$ Stockholm Environment Institute, Environment Dept., University of York, York, UK
}

Correspondence to: S. R. Arnold (s.arnold@leeds.ac.uk)

Received: 26 July 2011 - Published in Biogeosciences Discuss.: 26 August 2011

Revised: 22 December 2011 - Accepted: 28 December 2011 - Published: 16 January 2012

\begin{abstract}
Using a global atmospheric chemistry model, we have quantified for the first time, intercontinental transboundary contributions to crop ozone exposure and subsequent yield reductions in the Northern Hemisphere. We apply four metrics (AOT40, M7, M12, W126) to assess the impacts of $100 \%$ reductions in anthropogenic $\mathrm{NO}_{\mathrm{x}}$ emissions from North (N) America, South East (SE) Asia and Europe on global and regional exposure of 6 major agricultural crop types to surface ozone, and resultant crop production losses during the year 2000 growing season. Using these metrics, model calculations show that for wheat, rice, cotton and potato, $100 \%$ reductions in SE Asian anthropogenic $\mathrm{NO}_{\mathrm{x}}$ emissions tend to produce the greatest global reduction in crop production losses (42.3-95.2\%), and a $100 \%$ reduction to $\mathrm{N}$ American anthropogenic $\mathrm{NO}_{\mathrm{x}}$ emissions results in the greatest global impact on crop production losses for maize and soybean (59.2-85.9\%). A $100 \%$ reduction in $\mathrm{N}$ American anthropogenic $\mathrm{NO}_{\mathrm{x}}$ emissions produces the largest transboundary impact, resulting in European production loss reductions of between $14.2 \%$ and $63.2 \%$. European $\mathrm{NO}_{\mathrm{x}}$ emissions tend to produce a smaller transboundary impact, due to inefficiency of transport from the European domain. The threshold nature of the AOT40 ozoneexposure metric results in strong dependence of non-local emissions impacts on the local ozone concentration distribution. Our calculations of absolute crop production change under emission reduction scenarios differ between the metrics used, however we find the relative importance of each region's transboundary impact remains robust between metrics. Our results demonstrate that local air quality and emission control strategies have the potential to partly alleviate ozone-induced crop yield loss in continents downstream, in addition to effectively mitigating local ozone-induced production losses.
\end{abstract}

\section{Introduction}

In recent decades tropospheric ozone has emerged as a global air pollution problem for human health and has also been observed to have harmful impacts on vegetation (Fuhrer and Achermann, 1994; Jager et al., 1996; United States Environment Protection Agency, USEPA 1996). Field experiments show ozone damage to result in yield reduction and deterioration in crop quality (Fuhrer, 2009). Ozone is produced insitu in the troposphere through a sequence of sunlight-driven photochemical reactions involving nitrogen oxides $\left(\mathrm{NO}_{\mathrm{x}}\right.$, encompassing both $\mathrm{NO}$ and $\mathrm{NO}_{2}$ ) and volatile organic compounds (VOCs) or CO (Crutzen et al., 1999). Since the pre-industrial period, anthropogenic emissions of $\mathrm{NO}_{\mathrm{x}}, \mathrm{CO}$, methane, and other VOCs have likely led to increased ambient ozone over many regions (Prather et al., 2001). Ozoneinduced crop yield reductions have been suggested to lead to economic loss and to threaten food security. This is of increasing concern, especially where the expanding economy has resulted in increased emissions of ozone precursors (Adams et al., 1982; Aunan et al., 2000; Holland et al., 2002; Li et al., 1999; Wang and Mauzerall, 2004).

Overall, emissions reductions in response to monitoring of exceedences of air quality standards (AQSs) set in health and vegetation exposure guidelines, have in part resulted in the decrease in the frequency of peak ozone levels since the 1990s (Lin et al., 2001; Soldberg and Lindskog, 2005). However as many economies are still growing rapidly (in particular those in southern and eastern Asia), the emission of ozone precursor trace gases in the Northern Hemisphere (NH) is expected to continue to rise (Zhang et al., 2009). Many observational and modelling studies have quantified contributions to regional surface ozone concentrations from import of ozone and its precursors from continental regions upwind 
(Hudman et al., 2004; Derwent et al., 2004; Dentener et al., 2010; Parrish et al., 2010). These studies have inferred contributions of between 2 and 10 ppbv to surface ozone in western Europe and western North (N) America from ozone precursor emissions in N America and Asia, respectively. European emissions also impact surface ozone in South East (SE) Asia by 0.2 to 3.5 ppbv (Duncan and Bey, 2004; Fiore et al., 2009; Wild et al., 2004). However, due to a paucity of strong cyclogenisis and frontal activity over Central and Eastern Europe, export of European emissions eastwards is somewhat less efficient compared with $\mathrm{N}$ American and Asian pollution export (Stohl, 2001). These inter-continental transport contributions to surface ozone can lead to exceedences of regional AQSs, and may become significant in the context of threshold limits for safe human health and vegetation exposure. As European and N American ozone precursor emissions continue to decline, rising East Asian emissions may play an increasing role in controlling $\mathrm{NH}$ background ozone (Cooper et al., 2010; Jacob et al., 1999), which has seen increases over the past $30 \mathrm{yr}$ (Cooper et al., 2010; Derwent et al., 2004). Intercontinental contributions to crop ozone exposure and yield reductions have not yet been quantified, but are important to understand in the context of expected future changes in ozone precursor emissions in the Northern Hemisphere and other environmental threats to food security.

Recent studies (Roy et al., 2009; Tong et al., 2009b; Van Dingenen et al., 2009; Averny et al., 2011a,b) have assessed the exposure of crops to ozone over various regions of the world using atmospheric models to provide the necessary regional or global ozone concentration fields for the analysis. Van Dingenen et al. (2009) estimate the global impact of surface ozone on four major agricultural crops (wheat, rice, soy and maize) under current and future emission scenarios, focusing in particular on the impact of relative yield losses on production losses in terms of the reduced yield due to ozone exposure and the associated economic losses. They estimated that present day yield losses (the reduction in yield compared to a theoretical case of no exposure of the crops to ozone) lie in the range of $7 \%$ and $12 \%$ for wheat, between $6 \%$ and $16 \%$ for soybean, between $3 \%$ and $4 \%$ for rice and between $3 \%$ and $5 \%$ for maize. Averny et al. (2011a) estimate similar yield losses for the year 2000 showing wheat relative yield losses of 3.9 to $15.4 \%$, soybean relative yield losses of 8.5 to $13.9 \%$ and maize yield losses of 2.2 to $5.5 \%$. Van Dingenen et al. (2009) also show that by 2030 (under a current legislation scenario) the global situation is expected to deteriorate mainly for wheat (additional 2-6\% loss globally) and rice (additional 1-2\% loss globally). They also estimated that using 2000 world market prices, the total global economic cost would be in the range of $\$ 14$ to $\$ 26$ billion. Averny et al. (2011b) also estimated the damage due to ozone exposure, showing that the projected global economic loss by 2030 would fall in the range of $\$ 12$ to $\$ 35$ billion (depending on emissions scenario used).
These studies aim to provide quantification of ozone damage to crops on a global, regional and national scale. However, no previous study has attempted to estimate the impact of ozone precursor emissions from each of the Northern Hemisphere's major industrialized regions on crop yields globally, locally and in continents downwind. In this study, we use a global chemical transport model to quantify the intercontinental contributions to ozone-induced crop production losses, due to anthropogenic $\mathrm{NO}_{\mathrm{x}}$ emissions from $\mathrm{N}$ America, SE Asia, and Europe. We compare a control simulation for 2000 against 3 different emissions scenarios where a $100 \%$ reduction is applied to anthropogenic $\mathrm{NO}_{\mathrm{x}}$ emissions in each of the 3 regions separately. We use these scenarios to quantify contributions to regional crop production losses of six major crop types, from emission reductions in each region, using a range of ozone exposure metrics (AOT40, Mx and W126). We aim to determine how the use of these different metrics impacts our conclusions regarding transboundary crop production loss contributions. Section 2 reviews the metrics used to assess the ozone exposure risk of vegetation. Section 3 describes the TOMCAT chemical transport model, the exposure response relationships used to quantify the impact of ozone exposure on crop relative yield loss and production and the crop data sets used in this study. Section 4 presents a model versus observations comparison of surface ozone concentrations and the different metrics along with the projected impact of the emissions reductions on crop production loss and the different impact on crop production figures. Section 5 discusses the estimated transboundary effects of the emissions cuts. The conclusions of this study are presented in Sect. 6 .

\section{Metrics used to assess ozone exposure risk of vegetation}

There have been a large number of field studies carried out to assess the response of crops to ozone exposure, especially in N America and Europe, and to a lesser extent in South and East Asia (Emberson et al., 2009). Mills et al. (2007) review two major studies: the US National Crop Loss Assessment Network (NCLAN) studies conducted in the 1980s (Heagle, 1989) and the European Open Top Chamber Programme (EOTCP) conducted in the late 1980s and early 1990s (Jager et al., 1992). These studies aimed to establish the response of crops to exposure to ozone and the resultant losses in yield. Mills et al. (2007) review a large set of crops to exposure to ozone data from a number of sources in the existing literature (including data from the above coordinated field experiments) in order to derive exposure-response functions for a set of 19 European agricultural and horticultural crops.

In addition to AQSs adopted to protect human health, AQSs for the protection of vegetation have been adopted in Europe (Fowler et al., 2008). Compared to those for vegetation, human exposure AQSs tend to focus on acute ozone 
pollution episodes rather than longer-term chronic exposure. As such, it is questionable whether human health AQSs will protect ecosystems. The AOT40 (accumulated exposure over a threshold of $40 \mathrm{ppbv}$ ) metric has been adopted in Europe (European Environment Agency, EEA 1999), to assess risk to vegetation from ozone exposure, and has been used to estimate changes in crop yield losses due to ozone exposure in different global regions (Van Dingenen et al., 2009; Wang and Mauzerall, 2004). The United Nations Economic Commission for Europe (UNECE), and the World Meteorological Organization (WMO) set a critical threshold value of AOT40 at 3 ppm h daylight hour accumulated ozone exposure, which should not be exceeded during the plant growing season (WHO, 2000). In the United States, as of 2007, the USEPA has set equal primary and secondary standards for the protection of human health and human welfare (including damage to crops) respectively, with a peak $8 \mathrm{~h}$ mean ozone concentration not to exceed $75 \mathrm{ppbv}$ more than three times a year (USEPA, 2010b). The USEPA is currently in the process of revising these AQSs (USEPA, 2010a).

The USEPA also proposed the W126 metric as a secondary standard to assess potential vegetation damage from ozone exposure (Federal Register, 2008). This is used by several Federal agencies in the United States as well as by researchers (Wang and Mauzerall, 2004). The W126 metric is defined as the sum of hourly ozone concentrations (weighted by a sigmoidal weighting function) during daylight hours through the period of a crop growing season. W126 does not have a threshold value but the weighting function places more emphasis on higher ozone concentrations, hence like AOT40, W126 acts to emphasize both the peak and duration of ozone concentrations to which vegetation is exposed (Tong et al., 2009a).

A third set of standards developed to assess ozone impacts on vegetation are M7 and M12 (collectively referred to as Mx), as described in (Tong et al., 2009a). These indices are calculated over 3 consecutive months of a plant growing season, and defined as the mean daytime $7 \mathrm{~h}$ (M7) and $12 \mathrm{~h}$ (M12) surface ozone concentrations. These indices differ from AOT40 and W126 in that they apply equal weighting to all ozone concentrations to which the plant is exposed. As the $\mathrm{Mx}$ indices are calculated during daylight hours, all ozone concentrations during this period contribute equally. Table 1 shows the definitions of each of the indices.

The Mx indices have been criticised for their inability to characterize different types of exposure regimes, partly as they have the potential to put more emphasis on the more numerous but less biologically significant lower ozone concentrations. However, concentrations that are less important in terms of plant damage are still able to cause some reduction in crop yields (Heck and Colwing, 1997). Using $\mathrm{Mx}$ can therefore account for any yield losses resulting from ozone concentrations of less than $40 \mathrm{ppbv}$, and the defined Mx Weibull relationship (see Table 2) used to relate ozone exposure to damage, results in less predicted damage at these
Table 1. Definitions of the ozone exposure indices used in this study. $n$ is the number of hours in the growing season, $\mathrm{C}$ is the hourly ozone concentration and $i$ is the hour index.

\begin{tabular}{llc}
\hline Index & Definition & Unit \\
\hline AOT40 & $\begin{array}{l}\text { AOT40 }=\sum_{i=1}^{n}[\mathrm{C}-40]_{i} \\
\text { for } \mathrm{C} \geq 40 \mathrm{ppbv}\end{array}$ & $\mathrm{ppm} \mathrm{h}$ \\
\hline M7 & $\begin{array}{l}\text { M7 }=\frac{1}{n} \sum_{i=1}^{n}[\mathrm{C}]_{i} \\
\text { for 09:00-15:59h C }\end{array}$ & $\mathrm{ppbv}$ \\
\hline M12 & $\begin{array}{l}\text { M12 }=\frac{1}{n} \sum_{i=1}^{n}[\mathrm{C}]_{i} \\
\text { for 08:00-19:59h C }\end{array}$ & $\mathrm{ppbv}$ \\
\hline W126 & $\begin{array}{l}\mathrm{W} 126=\sum_{i=1}^{n}\left[\frac{C}{1+4403 \exp (-0.126 \times C)}\right]_{i} \\
\text { for C } \geq 0 \mathrm{ppmv}\end{array}$ & $\mathrm{ppm} \mathrm{h}$ \\
\hline
\end{tabular}

lower ozone concentrations. This Weibull relationship can lead to a less severe, but similar threshold behviour to that of the other metrics. These nuances are important to understand, especially since it has been demonstrated that damage to crops can still occur below $40 \mathrm{ppbv}$ ozone exposure (Ashmore, 2005; Sitch et al., 2007; Mills et al., 2011a).

M7 and M12 have been used in a number of modelling studies to assess the impact of ozone on crop damage. Tong et al. (2009a) used a number of exposure and concentration based indices (including Mx, AOT40 and W126) to assess vegetation exposure to ozone over the United States using an air quality forecast model. M7 and M12 were also used in the USEPA's National Crop Loss Assessment Network (NCLAN) (Heck et al., 1984). Van Dingenen et al. (2009) concluded that AOT40's high sensitivity to small changes in ozone concentration close to the $40 \mathrm{ppbv}$ threshold and to uncertainties in ozone concentration, made it less suitable as an indicator for crop losses in modelling-based studies. They also concluded that M7 can be more satisfactorily modelled, but is considered a less suitable indicator for crop exposure. Tong et al. (2009a) showed that W126, despite not having a threshold value, performed less satisfactorily from a modelling point of view, due to its weighting function putting more emphasis on higher ozone concentrations for which biases between the modelled and observed concentrations are larger.

An important aspect to consider is that the AOT40 index was designed to capture the most harmful effects from episodic ozone pollution. However now that background levels of ozone are increasing (Cooper et al., 2010; Derwent et al., 2004) these threshold indices are starting to become less useful. It has also been highlighted in previous modelling studies that large uncertainties can arise in using these exposure based indices to estimate yield loss from model ozone fields (Tong et al., 2009a; Van Dingenen et al., 2009). A more accurate approach is to develop plant response relationships that are based on the flux of ozone into 

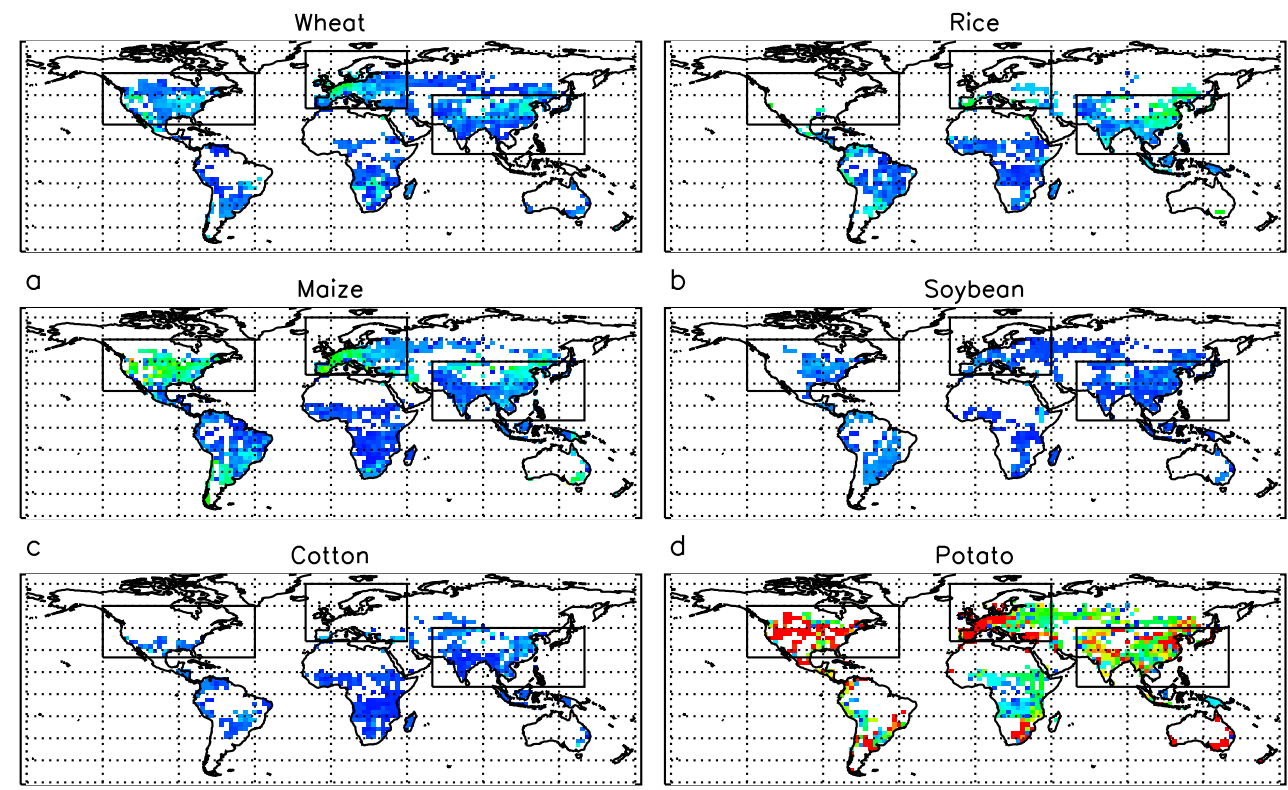

e

$f$

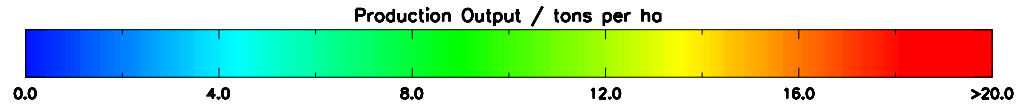

Fig. 1. SAGE group derived crop locations and production output for the six crop types considered, with emissions reduction regions (N America, Europe and SE Asia) overlaid.

the plant. However, at present flux-response relationships are only available for wheat and potato (Pleijel et al., 2004), and more recently tomato (Mills et al., 2011b). Not all of these have been parameterised for global application. As there is a much more comprehensive set of exposure-response relationships available to predict crop yield losses from the exposure based metrics, we have employed these here so that we can include a range of major crops, and compare our results across ozone-tolerant and ozone-sensitive crops. However, it should be noted that it is difficult to assess the suitability of these concentration based indices for application in regions different from those in which they were developed (Emberson et al., 2009). Future work is needed to develop and implement flux-based metrics for predicting yield losses on the global scale.

\section{Methodology}

\subsection{TOMCAT Chemical Transport Model and emissions scenarios}

The global 3-D TOMCAT chemical transport model (CTM) (Arnold et al., 2005; Chipperfield, 2006) is used to simulate hourly global tropospheric ozone for the year 2000 under the control and each of the 3 emissions reduction scenarios. TOMCAT is forced using offline ERA-interim meteorological data from the European Centre for Medium
Range Weather Forecasts (ECMWF), at a horizontal resolution of $\sim 2.8^{\circ} \times \sim 2.8^{\circ}$ with 31 hybrid sigma-pressure levels from the surface to $10 \mathrm{hPa}$. Sub-grid transport from convection (Stockwell and Chipperfield, 1999) and boundary layer turbulence (Holstag and Boville, 1993) is parameterised. The model tropospheric chemistry includes methane, $\mathrm{NO}_{\mathrm{x}}, \mathrm{C} 2-\mathrm{C} 3$ VOCs, isoprene photochemistry, wet and dry deposition (Giannakopoulos et al., 1999), and $\mathrm{NO}_{\mathrm{x}}$ emissions from lightning (Stockwell et al., 1999). Anthropogenic emissions were prescribed using the IPCC AR5 2000 emissions set (Lamarque et al., 2010) along with biomass burning emissions climatology from the Global Fire Emissions Database version 2 (GFED2) described in (van der Werf et al., 2006). In addition biogenic emissions were prescribed from the POET (Precursors of Ozone and their Effects in the Troposphere) database, used as described in Emmons et al. (2010). In order to assess the contribution from anthropogenic $\mathrm{NO}_{\mathrm{x}}$ emissions from $\mathrm{N}$ America, SE Asia, and Europe to ozone-induced crop damage, we repeat simulations for the year 2000 applying a $100 \%$ reduction to anthropogenic $\mathrm{NO}_{\mathrm{x}}$ emissions over each of the source regions shown in Fig. 1.

The overall goal of this study is to quantify the extent to which anthropogenic $\mathrm{NO}_{\mathrm{x}}$ emissions from the major industrialised regions in the northern hemisphere contribute to ozone-induced crop yield losses, with an emphasis on quantifying trans-boundary impacts. To achieve this it was 
Table 2. Ozone exposure/dose response functions for wheat, rice, maize, soybean, cotton and potato based on the AOT40, M7, M12 and W126 indices. The AOT40 relationships are described in Mills et al. (2007). The M7, M12, and W126 relationships are described in Wang and Mauzerall (2004).

\begin{tabular}{|c|c|c|}
\hline Crop & Metric & Exposure/dose response function: RY \\
\hline \multirow[t]{3}{*}{ Wheat } & AOT40 & $\mathrm{RY}=-0.0161 \mathrm{AOT} 40+0.99$ \\
\hline & M7 & $\mathrm{RY}=\exp \left[-(\mathrm{M} 7 / 137)^{2.34}\right] / \exp \left[-(25 / 137)^{2.34}\right]$ \\
\hline & W126 & $\mathrm{RY}=\exp \left[-(\mathrm{W} 126 / 51.2)^{1.747}\right]$ \\
\hline \multirow[t]{2}{*}{ Rice } & AOT40 & $\mathrm{RY}=-0.0039 \mathrm{AOT} 40+0.94$ \\
\hline & M7 & $\mathrm{RY}=\exp \left[-(\mathrm{M} 7 / 202)^{2.47}\right] / \exp \left[-(25 / 202)^{2.47}\right]$ \\
\hline \multirow[t]{3}{*}{ Maize } & AOT40 & $\mathrm{RY}=-0.0036 \mathrm{AOT} 40+1.02$ \\
\hline & M12 & $\mathrm{RY}=\exp \left[-(\mathrm{M} 12 / 124)^{2.83}\right] / \exp \left[-(20 / 124)^{2.83}\right]$ \\
\hline & W126 & $\mathrm{RY}=\exp \left[-(\mathrm{W} 126 / 93.7)^{3.392}\right]$ \\
\hline \multirow[t]{3}{*}{ Soybean } & AOT40 & $\mathrm{RY}=-0.0116 \mathrm{AOT} 40+1.02$ \\
\hline & M12 & $\mathrm{RY}=\exp \left[-(\mathrm{M} 12 / 107)^{1.58}\right] / \exp \left[-(20 / 107)^{1.58}\right]$ \\
\hline & W126 & $\mathrm{RY}=\exp \left[-(\mathrm{W} 126 / 109.75)^{1.2315}\right]$ \\
\hline Cotton & AOT40 & $\mathrm{RY}=-0.016 \mathrm{AOT} 40+1.07$ \\
\hline Potato & AOT40 & $\mathrm{RY}=-0.0057 \mathrm{AOT} 40+0.99$ \\
\hline
\end{tabular}

necessary to apply $100 \%$ reductions to anthropogenic $\mathrm{NO}_{\mathrm{x}}$ sources. Production of ozone in the troposphere varies nonlinearly with changes to $\mathrm{NO}_{\mathrm{x}}$ emissions. Hence, scaling from a more attainable emissions reduction of e.g. $20 \%$ to total attribution is not trivial. Wild et al. (2011) and references therein show that scaling a $20 \%$ emissions reduction by a factor of 5 can underestimate the response to a $100 \%$ reduction. In the case of $\mathrm{NO}_{\mathrm{x}}$ emissions, this non-scalable behaviour shows a strong seasonal dependence. In addition, the threshold nature of the AOT40 index means that its response to ozone precursor emission changes are not scalable.

In our simulations, emission cuts are applied only to anthropogenic surface emissions of $\mathrm{NO}_{\mathrm{x}}$. Biomass burning and natural $\mathrm{NO}_{\mathrm{x}}$ emissions remain unchanged between the different scenarios. We have not changed aircraft emissions of $\mathrm{NO}_{\mathrm{x}}$ between simulations, since it is difficult to regionalize these emissions in terms of their attribution. Figure 2 shows $\mathrm{NO}_{\mathrm{x}}$ emissions under the control and each of the emissions reduction scenarios. Hourly ozone concentrations were output from the midpoint of the lowest model layer, which is $\sim 30 \mathrm{~m}$ above the surface. To account for the concentration gradient of ozone in the lowest model layer (produced by deposition to the surface), we scaled the model ozone to crop canopy height (assumed to be $1 \mathrm{~m}$ ), using the approach of the Long-range Transboundary Air Pollution (LRTAP) Convention 2004, as described by Tuovinen et al. (2007).

\subsection{Calculation of ozone exposure metrics and relative yield loss}

The Mx, AOT40 and W126 exposure indices are calculated using modelled hourly ozone (scaled to crop canopy height). Using model AOT40, we calculate the relative yield loss for 6 major crops: wheat, rice, maize, soybean, cotton and potato (Fig. 1). We use Mx to calculate relative yield loss for 4 of the crops (wheat, rice, maize and soybean). The W126 index is used to calculate relative yield loss for 3 of the crops (wheat, maize and soybean). The choice of crops for each index is limited by the availability of exposure-response functions. Values are accumulated over a crop-specific growing season which we define as the period between the planting date and the harvesting date for each of the crops considered (see Sect. 3.3). The use of crop-specific growing seasons allows a more realistic estimation of the exposure of crops to ozone damage, each of which grow for different periods of time in different locations. For Mx we calculate $7 \mathrm{~h}$ and $12 \mathrm{~h}$ daytime mean ozone over the duration of the same growing season used for AOT40. We follow the approach of previous studies (Roy et al., 2009; Van Dingenen et al., 2009) and define daylight hours as a fixed 12-h period running from 08:00 to 19:59 local time (LT) for the calculation of AOT40, M12 and W126. For M7 we use a 7-h time period of 09:00 to 15:59 LT.

Relative yield for each crop is calculated based on the exposure-response relationships compiled by Mills et al. (2007), which give linear exposure-response relationships as a function of AOT40 for the crops considered (Table 2). Using AOT40, allows us to consistently assess the impact of ozone exposure on both ozone sensitive (wheat, soybean and cotton) and moderately ozone tolerant (rice, maize and potato) crop types.

The AOT40 exposure-response relationships tend to have an intercept that is not equal to 1 . In the case of some crops this can produce an offset that is high compared to the slope of the exposure-response relationship. Therefore we have adopted a similar approach to that used in Van Dingenen et al. (2009) and scaled the exposure response functions to their value at AOT $40=0$ such that the relative yield is equal to 1 at zero exposure. Table 2 also summarises 


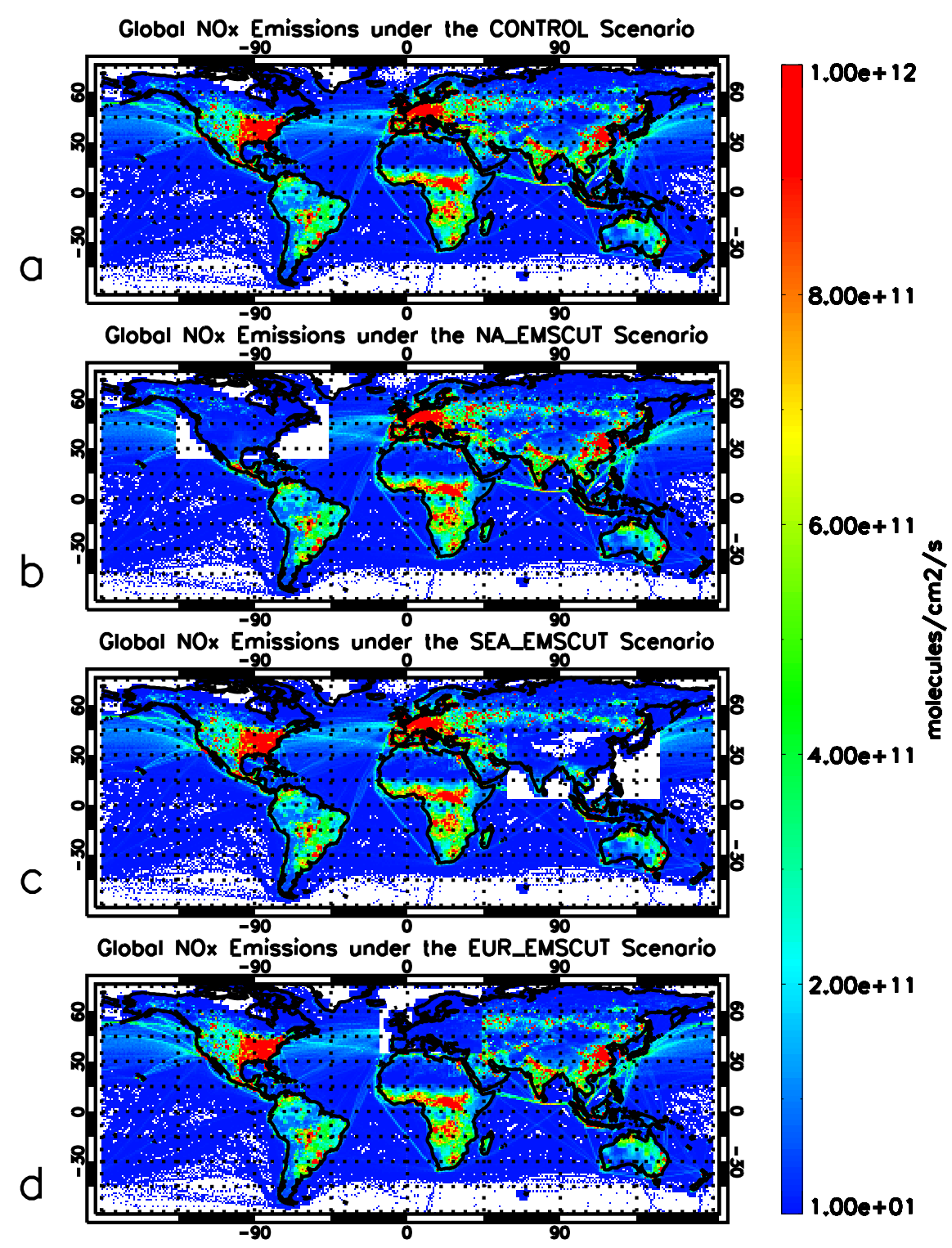

Fig. 2. Global surface $\mathrm{NO}_{\mathrm{x}}$ emission distributions under (a) the control and (b-d) each of the emissions cut scenarios.

the exposure response relationships for the calculation of relative yield loss for wheat, rice, maize and soybean using Mx and wheat, maize and soybean using W126 from Wang and Mauzerall (2004).

\subsection{Crop data and calculation of crop production loss}

We use the distributions and growing seasons for each crop from crop datasets from the Center for Sustainability and the Global Environment (SAGE) group at the University of Wisconsin (Sacks et al., 2010). These provide global-scale crop planting and harvesting dates for 19 widely-grown crops, covering $71 \%$ of the world's crop growing areas, and harvested area and production output for 175 distinct crops of the world (Monfreda et al., 2008). The data are pro- vided on a $\sim 10 \mathrm{~km}$ by $10 \mathrm{~km}$ ( 5 min resolution) latitudelongitude grid and are produced by combining national, state and county level census statistics from 206 countries, and planting and harvesting dates from national and sub-national levels. Global maps of the crop locations are shown in Fig. 1.

We make use of the filled version of the crop calendar datasets which provide a location-specific planting and harvesting date for every land point on the globe for each of the six major crop types we consider. The crop location and harvest data are regridded to the $\sim 2.8 \times 2.8^{\circ}$ TOMCAT horizontal resolution. We define the crop-specific growing season as the time in days between the planting and harvesting date for each land model gridbox. 

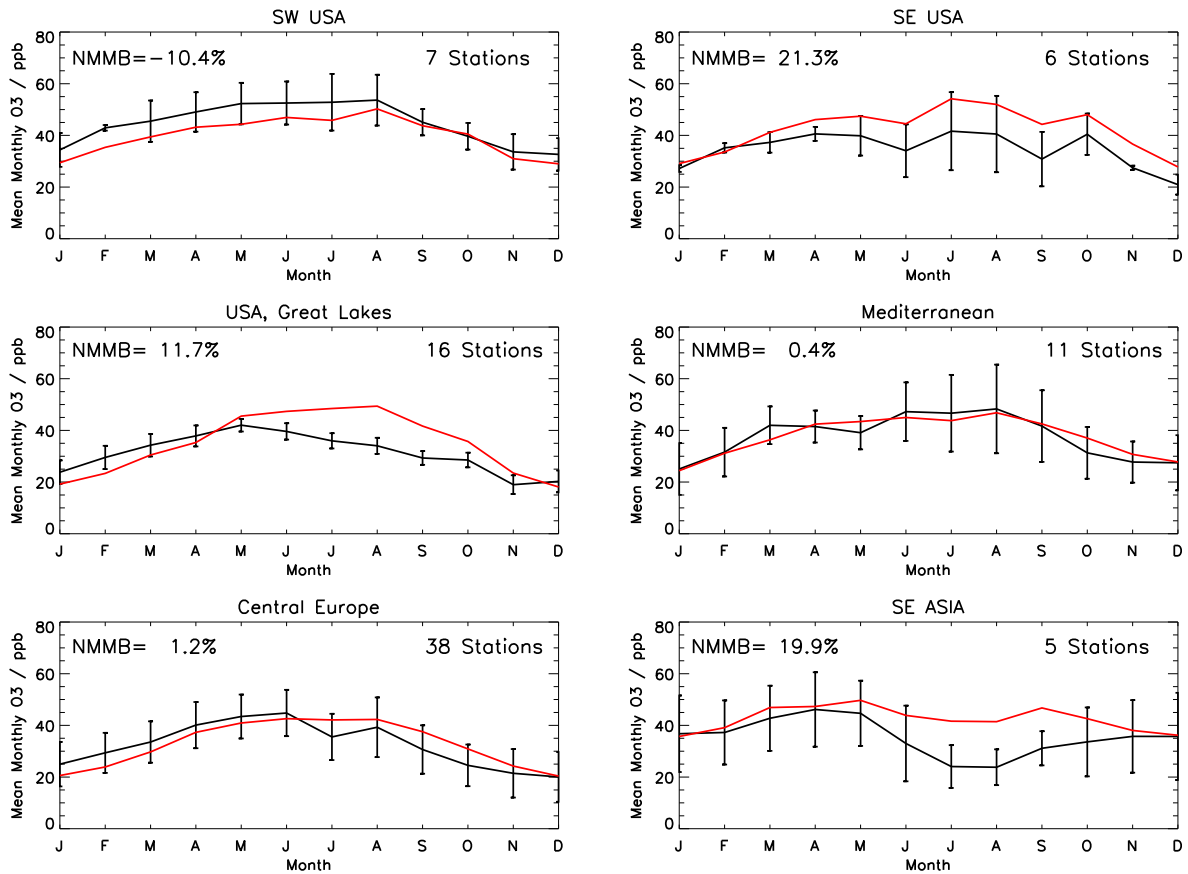

Fig. 3. Regionally-averaged monthly-mean surface ozone concentrations from monitoring stations (black line) and the TOMCAT model under the control scenario (red line) for the year 2000. The model results are the means for the model gridboxes where the stations are located with the model ozone concentration scaled from $30 \mathrm{~m}$ (centre of surface gridbox) to $10 \mathrm{~m}$ (measurement sample height). Error bars indicate 1 standard deviation on the monthly mean observations. The normalised model mean bias (NMMB) is indicated for each region.

We calculate AOT40, Mx and W126 for each crop on a global scale over the crop-specific growing seasons and then use the crop data to quantify regionally-aggregated relative yield losses (mean yield loss weighted according to area harvested and crop production output within each region) for each of the six major crops.

Crop production loss (CPL) is calculated based upon the relative yield loss, and the production output data:

$\mathrm{CPL}=\frac{\mathrm{RYL}}{1-\mathrm{RYL}} \times \mathrm{CP}$

where $\mathrm{CP}$ is the annual yield produced for each crop in the year 2000 given by Monfreda et al. (2008). We calculate CPL for each of the six crops on a global scale and over each of the $3 \mathrm{NH}$ regions considered.

\subsection{Model evaluation}

Modelled surface ozone is evaluated using hourly ozone observations from the year 2000 averaged over several sites within each region, which is mainly taken from continuous ground based UV absorption based measurements. We make use of data from the European Monitoring and Evaluation Programme (EMEP), the USEPA and the World Data Centre for Greenhouse Gases (WDCGG). We use sites from varied location types, including both urban and rural locations, as well as coastal and inland locations, to provide coverage across polluted and relatively clean air locations. We have used sites from Japan, Malaysia, Nepal and China for the monthly-mean comparison over Asia, as these sites provided the best continuous surface level ozone on a monthly basis. Outside of Europe and N America, we have used observations from the year 2000 where possible, but generally the ozone data used falls within the range 1995-2010 according to data availability. Hourly model output is taken from grid boxes containing each observation site position, before being averaged across sites within each region. Table 3, provides a summary of the regions compared as well as information on the sources of the observations. We compare modelled and observed monthly-mean ozone, as well as the AOT40, Mx and W126 metrics where hourly observations allow.

\section{Results}

\subsection{Comparison of model ozone concentrations and metrics with observations}

Figure 3 shows observed and modelled monthly-mean ozone concentrations from the year 2000 control simulation for regions considered in the study. For these comparisons, the model ozone at $30 \mathrm{~m}$ (the mid-point of the lowest model layer) was scaled using the approach of the LRTAP Convention (2004) to a height of $10 \mathrm{~m}$, the height at which most of the observations are made. 
Table 3. Summary of regions used and data sources for model evaluation.

\begin{tabular}{lrrcl}
\hline Region & lon, lat $(\min )$ & lon, lat $(\max )$ & \# of stations & References \\
\hline South-West USA & $-125,30$ & $-110,40$ & 7 & CASTNET: Clean air Status and Trends Network $^{1}$ \\
South-East USA & $-90,25$ & $-80,35$ & 6 & CASTNET: Clean air Status and Trends Network $^{1}$ \\
Great-Lakes USA & $-95,40$ & $-75,50$ & 16 & CASTNET: Clean air Status and Trends Network $^{1}$ \\
Mediterranean & 5,35 & 30,45 & 11 & EMEP: European Monitoring and Evaluation Programme \\
Central Europe & 7,48 & 17,54 & 38 & EMEP: European Monitorinf and Evaluation Programme \\
South-East Asia & 110,20 & 125,35 & 5 & WDCGG: World Data Centre for Greenhouse Gases \\
\end{tabular}

${ }^{1}$ CASTNET: http://java.epa.gov/castnet/epa_jsp/prepackageddata.jsp\#ozone ${ }^{2}$ EMEP: http://tarantula.nilu.no/projects/ccc/emepdata.html ${ }^{3}$ WDCGG: http://gaw.kishou.go.jp/ cgi-bin/wdcgg/catalogue.cgi
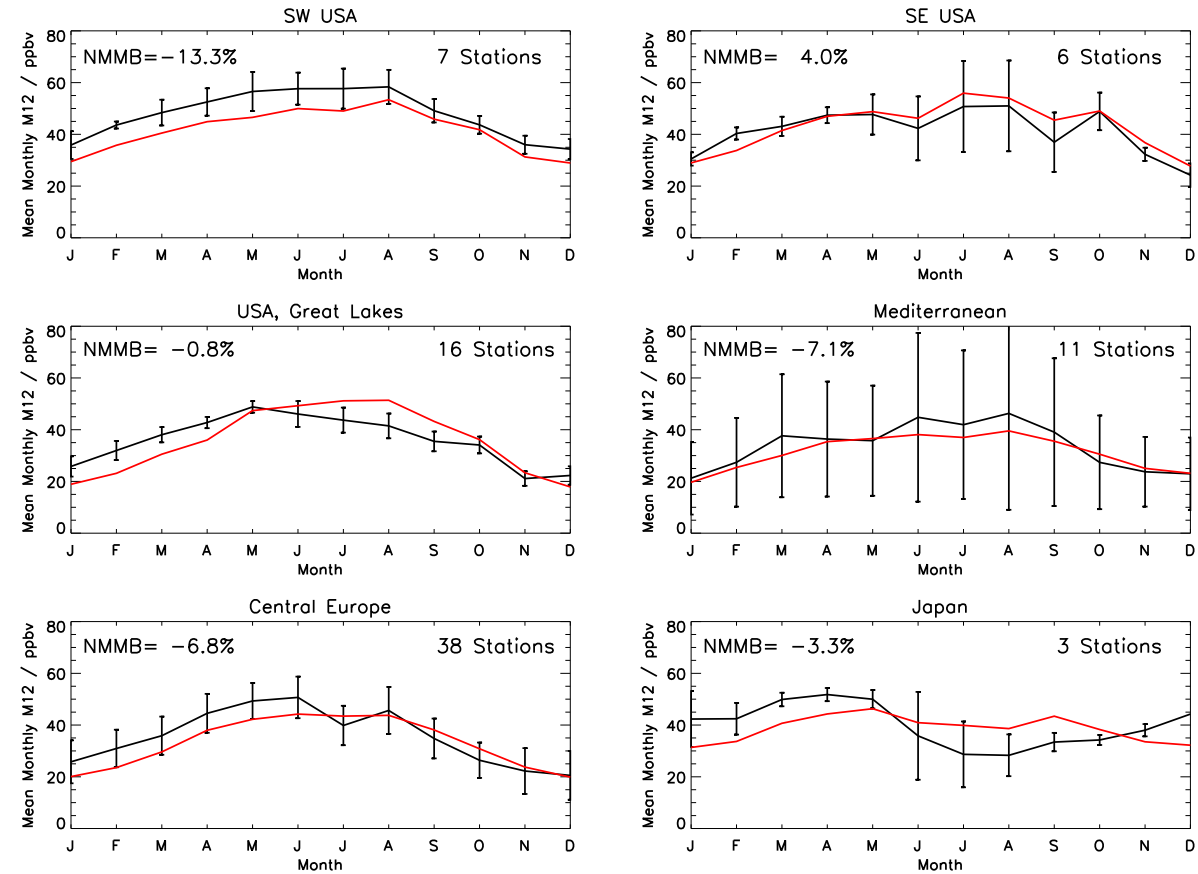

Fig. 4. As Figure 3, but for the monthly-average M12 metric (see main text for definition).

The model performs well over Mediterranean, Central Europe and SW USA with normalized model mean biases of $-10.4 \%$ to $1.2 \%$. There is less good agreement over SE USA (21.3\% bias) and SE Asia (19.9\% bias), where the model overestimates observed ozone throughout the summer months. Over the Great Lakes, the model tends to perform better with a model mean bias of $11.7 \%$ however summer ozone is also overestimated. Mean model surface ozone peaks above the $40 \mathrm{ppbv}$ threshold limit of AOT40, over SW USA, and Central Europe during the summer months and over the Great Lakes and SE USA during the spring, which coincides with the growing season for many crops in the $\mathrm{NH}$. Over SE Asia, a less distinct seasonal surface ozone cycle is seen due to the majority of the region lying within the tropical latitudes, where seasonality in insolation and its impacts on photochemistry are less pronounced. The positive model bias over SE Asia during the summer months could also be linked to the model inaccurately representing the monsoon period over SE Asia which typically runs from July to October. The monsoon brings the transport of marine air masses and weak photochemical activity, resulting in lower ozone concentrations than those during the pre-monsoon period (Zhao et al., 2010).

Figures 4, 5 and 6 compare model and observed M12, AOT40 and W126 indices respectively. The same regions are considered as in Fig. 3, except that SE Asia considers only Japan, since this is the only location in the region with continuous hourly surface ozone observations.

The M12 index shows good agreement over SE USA, the Mediterranean and Central Europe with the model mean biases falling between $-7.1 \%$ and $4 \%$. One particular region to note is SE USA, which sees a large improvement 

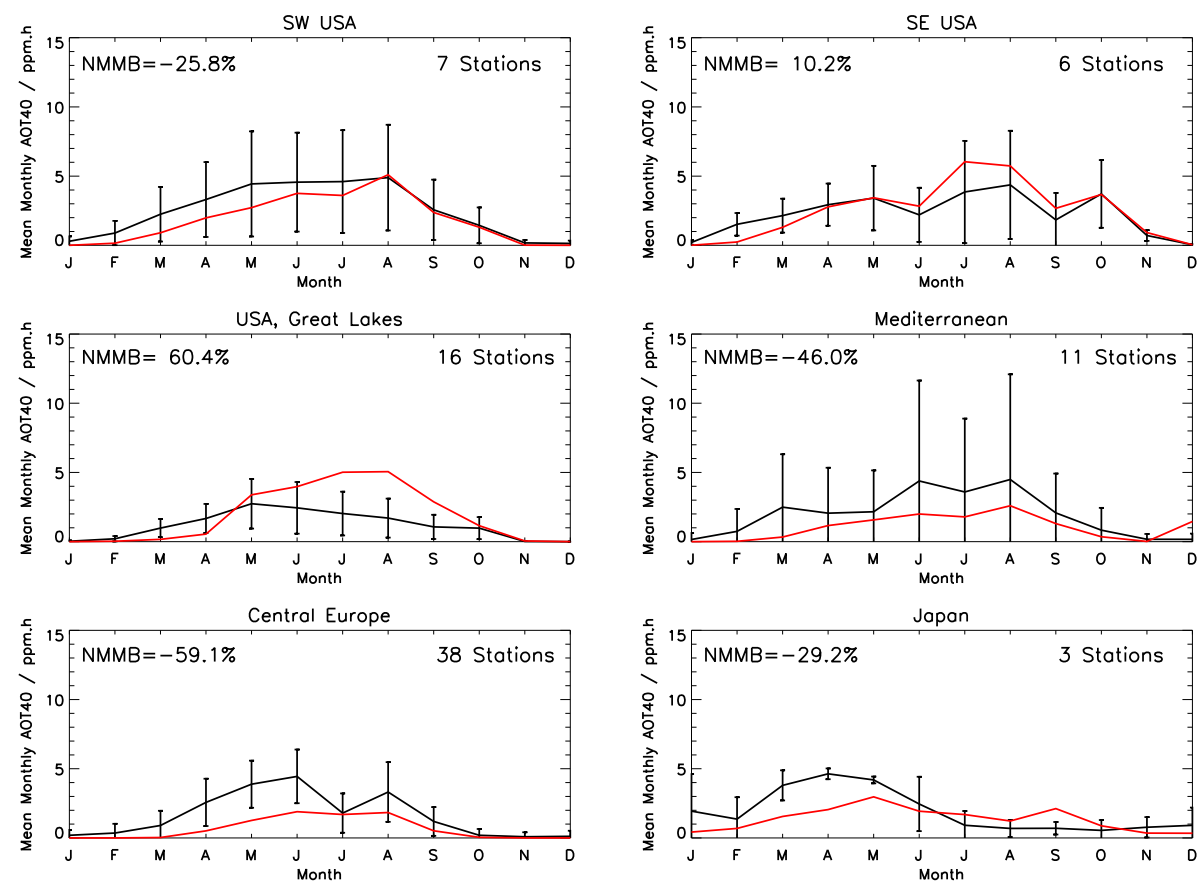

Fig. 5. As Figure 3, but for the monthly-accumulated AOT40 metric (see main text for definition).
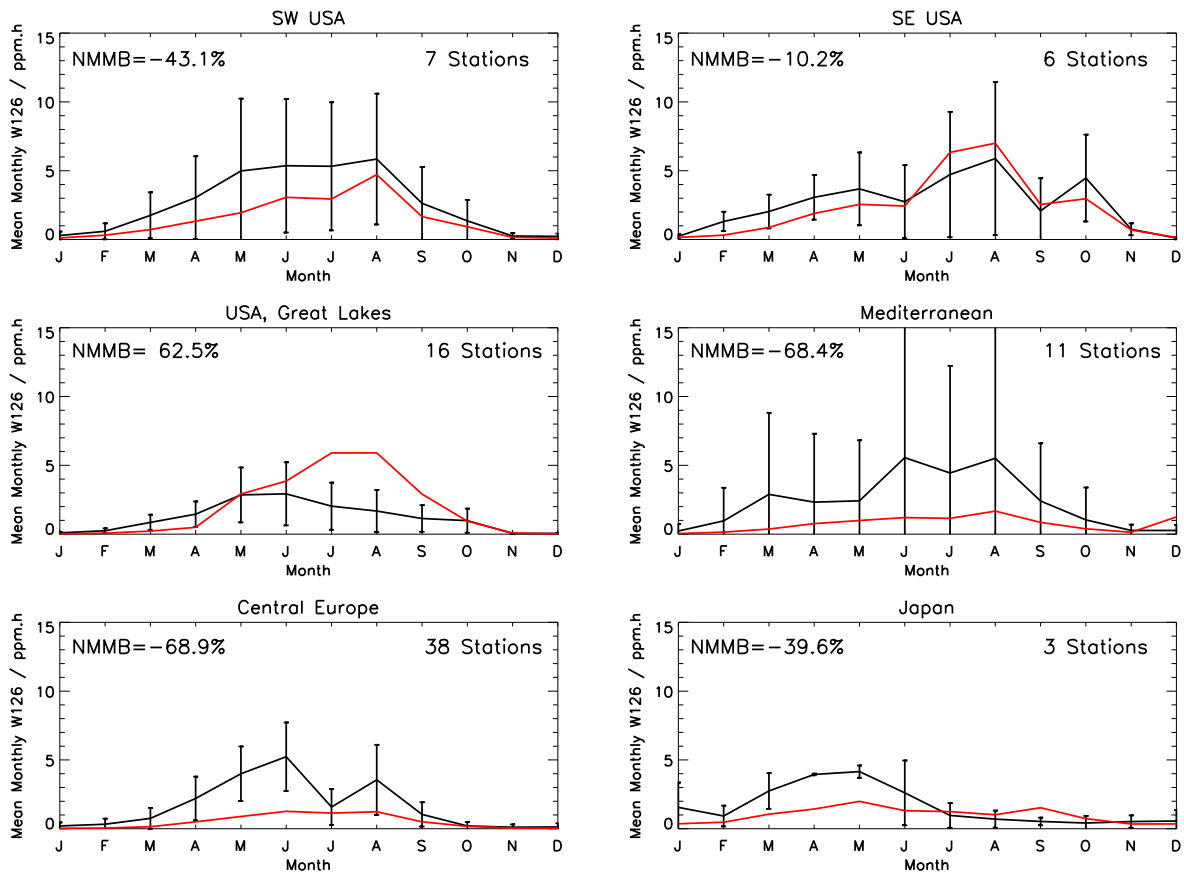

Fig. 6. As Figure 3, but for the monthly-average W126 metric (see main text for definition).

in agreement between the model and observed M12 compared to the comparison of monthly-mean ozone concentration. This indicates that the model over-predicts nighttime ozone. This may be linked to the surface model ozone having a potential positive bias in regions where model vertical mixing may be suppressed, as suggested by (Averny et al., 2011a) who also showed positive model biases over eastern parts of the United States. Over SW USA the model tends to underestimate observed M12, particularly during spring, where modelled M12 is about 5-10 ppbv less than observed. 

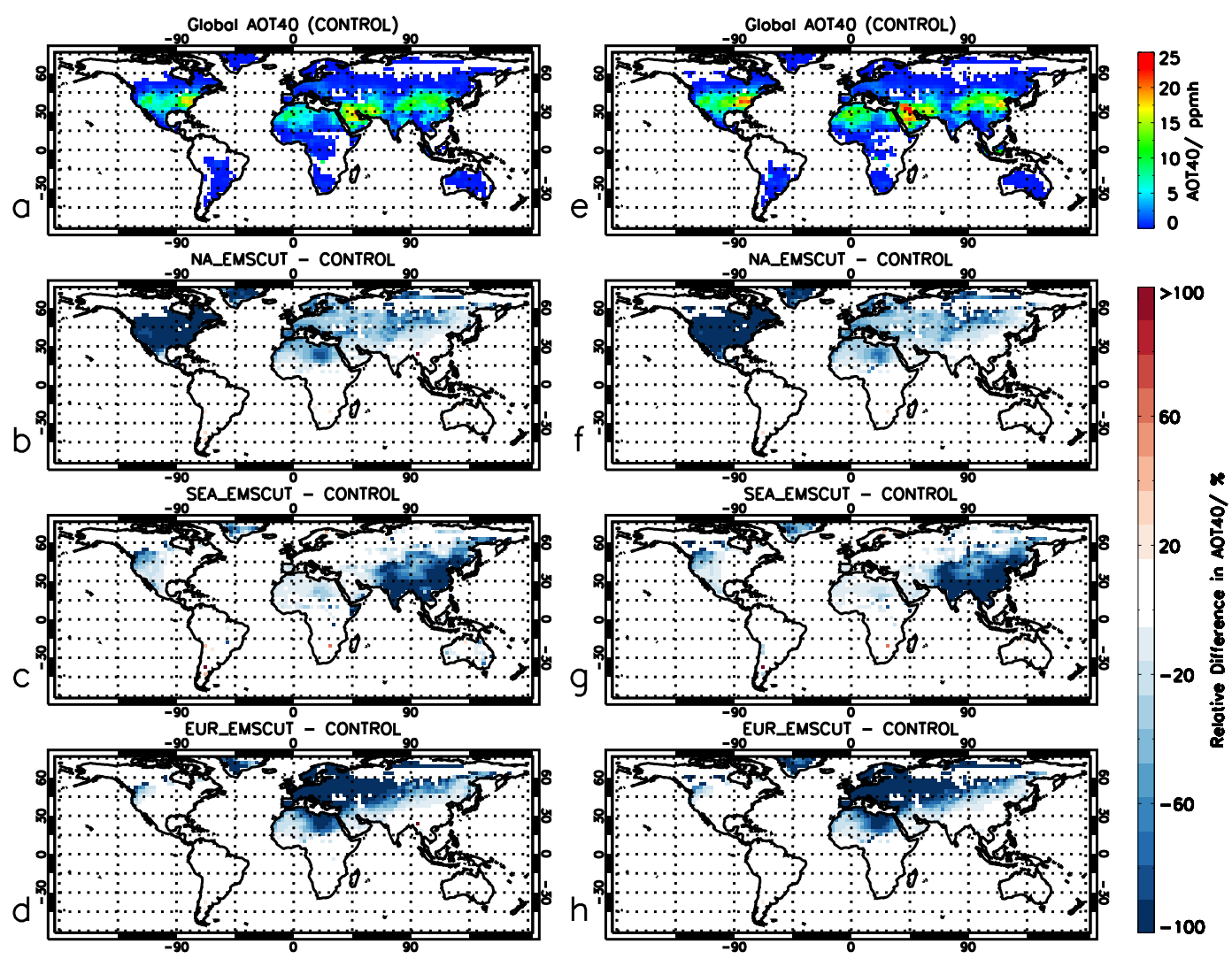

wheat growing season

rice growing season

Fig. 7. (a) Global AOT40 under the control model scenario for the wheat growing season; and relative difference in AOT40 between the control model and $100 \%$ cut in anthropogenic $\mathrm{NO}_{\mathrm{x}}$ emissions from (b) N America, (c) SE Asia, and (d) Europe for the same period. Panels (e-h) show the same but for the rice growing season.

Over Great lakes and Japan, model M12 falls within one standard deviation of the observations during the months of May, June and July (a typical growing season in the $\mathrm{NH}$ ) with the exception of throughout July over Great lakes. For these regions, model M12 generally has a low bias $(-0.8 \%$ and $-3.3 \%$ respectively). Overall, the model tends to overestimate summer M12 and underestimate spring M12.

The comparison of AOT40 shows similar modelobservation differences as M12 (Fig. 5). However, these differences are amplified due to the combination of the cumulative nature of the metric along with that of a non-zero threshold, as also shown by Tong et al. (2009a). The differences are greatest over Central Europe (model mean bias of -59.1\%) and the Great Lakes (model mean bias of $60.4 \%$ ) with the best agreement over SW USA, SE USA and the Mediterranean.

For W126, the best agreement is also seen over the SW USA, SE USA and Mediterranean, where the modelled metric falls within one standard deviation of the observed W126 (Fig. 6). The greatest differences are over Central Europe (model mean bias of $-68.9 \%$ ) and the Great Lakes (model mean bias of $62.5 \%$ ). These large model biases reflect the cumulative nature of the W126 metric.

While larger than the biases for M12, those for AOT40 are comparable to model biases found in the recent global ozone crop exposure study of Van Dingenen et al. (2009). These biases may indicate that from a modelling perspective, AOT40 and W126 are less robust for assessing crop exposure to ozone than the concentration average $\mathrm{Mx}$ indices. This has also been suggested by Tuovinen et al. (2007). To account for the impacts of these model biases on our results, we bias-correct the simulated exposure metrics (Mx, AOT40 and W126) that we use to estimate crop production losses under each emissions scenario. The bias corrections and their impacts are discussed further in Sect. 4.3.

\subsection{Changes to exposure metrics under emissions reductions scenarios}

Global relative differences in AOT40 between the control and each of the emissions reduction scenarios are shown in Fig. 7, along with global AOT40 calculated for control $\mathrm{NO}_{\mathrm{x}}$ 


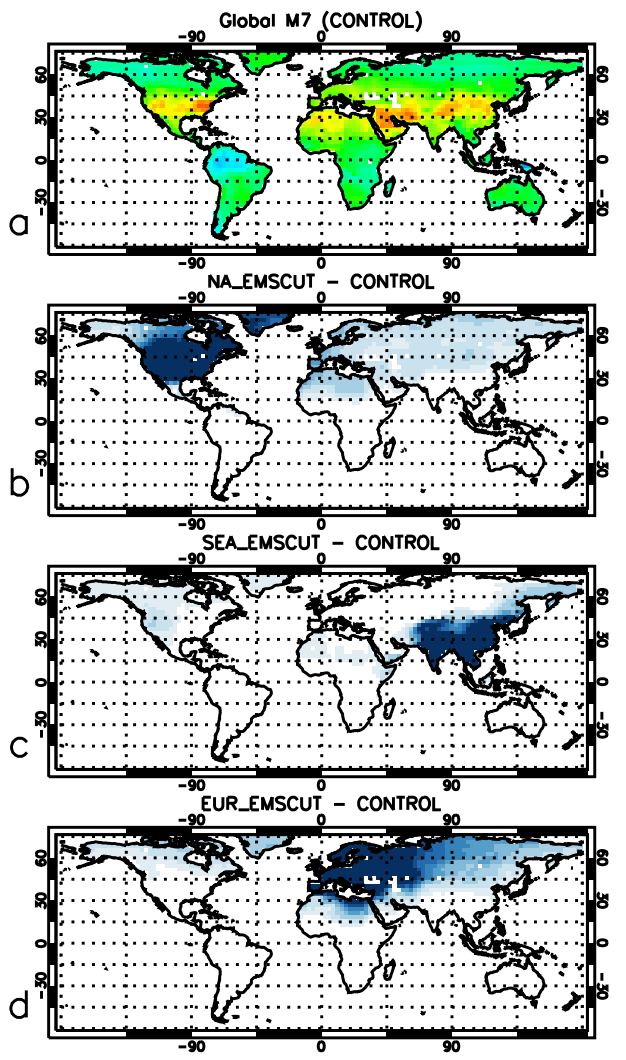

wheat growing season
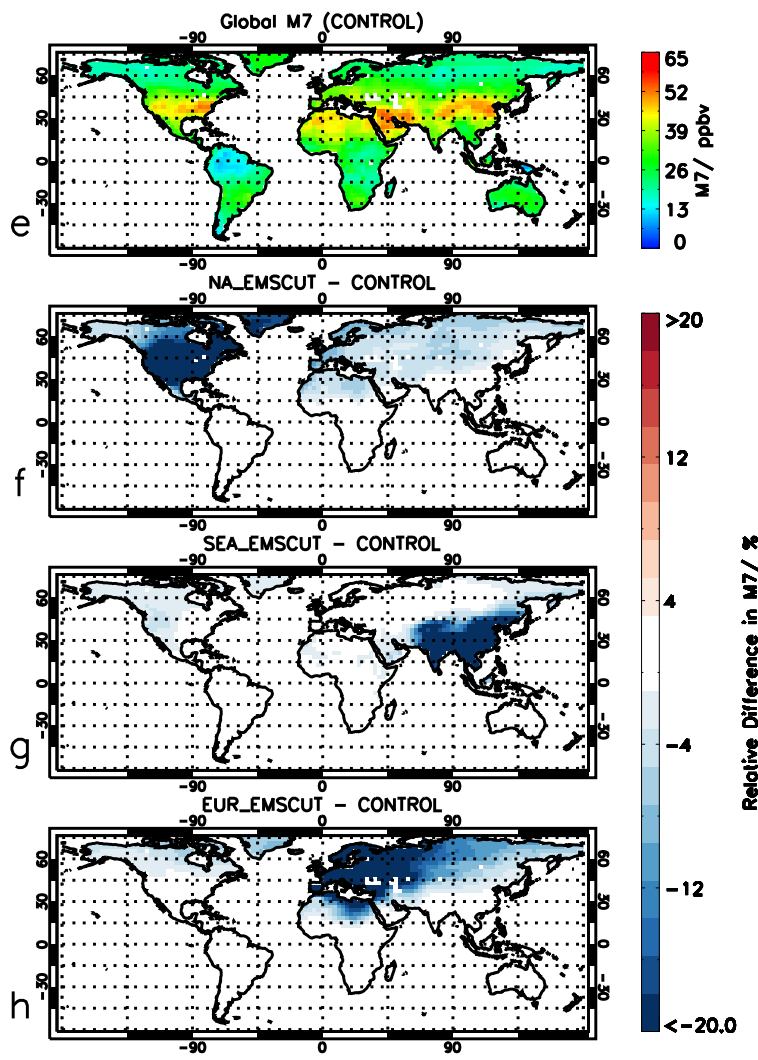

rice growing season

Fig. 8. As Figure 7 but for the M7 metric.

emissions over the growing seasons of two crops. Changes in AOT40 are shown for wheat (an ozone sensitive crop) and rice (an ozone tolerant crop). For both growing seasons the AOT40 index is particularly large over the major industrialized regions with peak AOT40 values approaching $20 \mathrm{ppm}$ h over the eastern seaboard of the United States as well as over eastern China and the Middle East. The overall pattern is similar for both crop growing seasons, and the remaining 4 crops' growing seasons (maize, soybean, cotton and potato) exhibit similar changes in AOT40 under each emissions reduction scenario (see Supplement). Local anthropogenic $\mathrm{NO}_{\mathrm{x}}$ emission cuts result in a near $100 \%$ relative decrease in AOT40 over each of the regions, although reductions over SE Asia are smaller ( $84.9 \%$ for wheat growing season and $87.6 \%$ for rice). The effect of anthropogenic $\mathrm{NO}_{\mathrm{x}}$ emissions from each of the regions on AOT40 in downstream receptor locations is also evident. A $100 \%$ reduction in $\mathrm{N}$ American anthropogenic $\mathrm{NO}_{\mathrm{x}}$ emissions results in mean relative decreases in AOT40 over the European region of $51.8 \%$ for the wheat growing season and $49.2 \%$ for rice, with decreases approaching $60 \%$ over parts of north and western Europe. This transboundary effect extends into SE Asia with mean relative decreases in AOT 40 of $\sim 16 \%$ (over both crop growing seasons) and greatest reductions in AOT40 over western and northern parts of the region. A $100 \%$ reduction in SE Asian anthropogenic $\mathrm{NO}_{\mathrm{x}}$ emissions results $19.9 \%$ to $21.0 \%$ (range for changes in AOT40 for both growing seasons) reduction in AOT40 over N America with greatest decreases in AOT40 over the western seaboard of the US and parts of Canada and Greenland where reductions in AOT40 approach $60 \%$. A smaller impact is seen over the European region, where mean reductions in AOT40 range from $3.2 \%$ to $4.2 \%$. The impact of a $100 \%$ reduction in European anthropogenic $\mathrm{NO}_{\mathrm{x}}$ emissions on AOT40 is slightly greater over SE Asia than over N America. Over SE Asia, mean regional relative decreases in AOT40 are $\sim 15 \%$ with greatest reductions seen over parts of north western China and western Mongolia. The impact on N American AOT40 is $\sim 11 \%$, with reductions in AOT40 approaching $40 \%$ over the west coast of the continental United States. Overall, reductions in anthropogenic $\mathrm{NO}_{\mathrm{x}}$ emissions over $\mathrm{N}$ America produce the largest global impact on AOT40, with N American $\mathrm{NO}_{\mathrm{x}}$ also producing the largest transboundary effect, shown by a mean reduction of $49.2 \%$ to $51.8 \%$ in AOT40 over Europe. Additional calculations (not shown) suggest that the relative importance of $\mathrm{NO}_{\mathrm{x}}$ emission reductions from each 

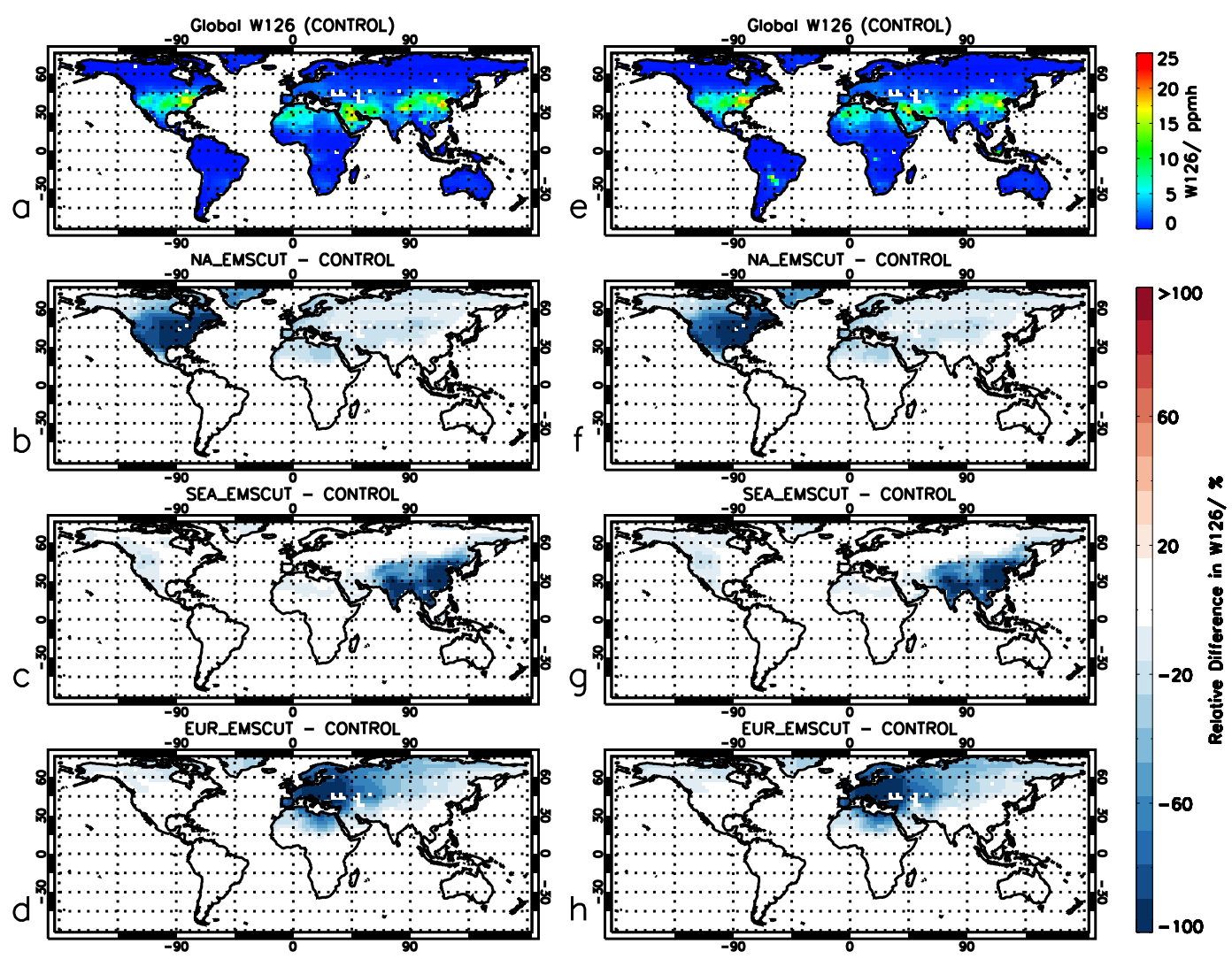

soybean growing season

maize growing season

Fig. 9. As Figure 7 but for the W126 index, and the soybean (a-d) and maize (e-h) growing seasons.

of the regions in reducing AOT exposure is invariant when the threshold of the AOT index is varied from 30 to $60 \mathrm{ppbv}$.

Figure 8 shows M7 mean ozone concentrations under the control scenario calculated over the same crops and growing seasons as for AOT40 (wheat and rice), and differences resulting from the three emission reduction scenarios. Anthropogenic $\mathrm{NO}_{\mathrm{x}}$ emission reductions result in local reductions of M7 of $20 \%$ or greater. Overall, the transboundary impacts of anthropogenic $\mathrm{NO}_{\mathrm{x}}$ emission reductions on $\mathrm{M} 7$ are less pronounced than those on AOT40. A $100 \%$ reduction in $\mathrm{N}$ American anthropogenic $\mathrm{NO}_{\mathrm{x}}$ emissions reduces M7 by $5.9 \%$ to $6.4 \%$ over Europe, with greatest reductions over north and western parts. The impact on SE Asia is much less, with reductions in $\mathrm{M} 7$ for the region of $2.0 \%$ to $2.4 \%$. A $100 \%$ reduction in SE Asian anthropogenic $\mathrm{NO}_{\mathrm{x}}$ emissions, results in decreases of $2.3 \%$ to $2.4 \%$ in $\mathrm{M} 7$ over the $\mathrm{N}$ American region, the largest reductions over western continental United States and Canada. The impact of the SE Asian emissions cuts on Europe is less than $1 \%$. Similar to AOT40, anthropogenic $\mathrm{NO}_{\mathrm{x}}$ emissions reductions over Europe tend to produce approximately similar reductions in M7 over the N American and SE Asian regions, with mean regional relative decreases in M7 slightly larger over SE Asia
(2.7\% for wheat growing season and $2.2 \%$ for rice) than over $\mathrm{N}$ America $(1.8 \%$ for wheat growing season and $1.9 \%$ for rice). Changes in the M12 metric over the maize and soybean growing season under each emissions scenario exhibit the same transboundary effects as those shown by M7 (see Supplement).

Results using the W126 metric are shown in Fig. 9 for maize and soybean. The transboundary impacts show the same pattern as those for AOT40, with N America producing the largest transboundary impact on W126 over Europe, where a $100 \%$ cut in anthropogenic $\mathrm{NO}_{\mathrm{x}}$ over $\mathrm{N}$ America results in a $25.1 \%$ decrease in European W126 during the soybean growing season and a $24.0 \%$ decrease during the maize growing season.

Overall, reductions in anthropogenic $\mathrm{NO}_{\mathrm{x}}$ emissions produce a similar pattern in the global AOT40, Mx and W126 fields with $\mathrm{N}$ American $\mathrm{NO}_{\mathrm{x}}$ producing the largest global scale impact. N American emission reductions exhibit the largest transboundary effect, shown by the response of a range of metrics over Europe to a $100 \%$ cut in anthropogenic $\mathrm{NO}_{\mathrm{x}}$ over $\mathrm{N}$ America. 
Table 4. Regionally-aggregated relative yield loss for the six crops under the model control scenario. M7 and M12 exposure response relationships are not available for potato and cotton. For these crops only yield losses based on AOT40 are presented. For W126 yield losses are shown for wheat, maize and soybean only. Values in brackets show bias-corrected results (see text for details).

\begin{tabular}{|c|c|c|c|c|}
\hline CONTROL & WORLD & N AMERICA & SE ASIA & EUROPE \\
\hline \multicolumn{5}{|l|}{ Wheat } \\
\hline AOT40 & $5.8(6.2) \%$ & $6.7(7.1) \%$ & $10.5(10.4) \%$ & $2.0(2.9) \%$ \\
\hline M7 & $3.2(3.5) \%$ & $3.3(3.8) \%$ & $4.5(4.4) \%$ & $2.6(3.2) \%$ \\
\hline W126 & $1.2(1.5) \%$ & $1.4(1.7) \%$ & $2.4(2.7) \%$ & $0.2(0.7) \%$ \\
\hline \multicolumn{5}{|l|}{ Rice } \\
\hline AOT40 & $1.4(1.4) \%$ & $3.2(3.4) \%$ & $1.6(1.6) \%$ & $0.7(1.0) \%$ \\
\hline M7 & $0.9(0.9) \%$ & $1.6(1.8) \%$ & $1.1(1.1) \%$ & $0.9(1.2) \%$ \\
\hline \multicolumn{5}{|l|}{ Maize } \\
\hline AOT40 & $2.5(2.6) \%$ & $3.5(3.7) \%$ & $3.1(3.1) \%$ & $0.7(1.0) \%$ \\
\hline M12 & $3.4(3.7) \%$ & $3.9(4.4) \%$ & $4.5(4.5) \%$ & $2.6(3.1) \%$ \\
\hline W126 & $0.04(0.06) \%$ & $0.05(0.08) \%$ & $0.07(0.08) \%$ & $0.0004(0.004) \%$ \\
\hline \multicolumn{5}{|l|}{ Soybean } \\
\hline AOT40 & $7.1(7.5) \%$ & $11.8(12.5) \%$ & $8.6(8.4) \%$ & $2.6(3.8) \%$ \\
\hline M12 & $10.5(11.4) \%$ & $15.1(16.3) \%$ & $13.7(13.5) \%$ & $10.3(11.9) \%$ \\
\hline W126 & $2.6(2.9) \%$ & $4.3(4.9) \%$ & $3.0(3.3) \%$ & $0.9(1.9) \%$ \\
\hline \multicolumn{5}{|l|}{ Cotton } \\
\hline AOT40 & $11.2(12.0) \%$ & $16.1(17.1) \%$ & $13.4(13.2) \%$ & $7.9(11.6) \%$ \\
\hline \multicolumn{5}{|l|}{ Potato } \\
\hline AOT40 & $1.9(2.0) \%$ & $2.5(2.6) \%$ & $4.5(4.4) \%$ & $0.4(0.7) \%$ \\
\hline
\end{tabular}

\subsection{Ozone-induced relative yield losses for 2000 under the model control scenario}

Table 4 shows regionally-aggregated ozone-induced relative yield losses for the control model scenario based on the different metrics derived from standard model ozone, and bias-corrected metrics. Bias-corrected values are calculated by normalising simulated values of the metrics in each source/receptor region by the regional modelled:observed ratios for each metric. For locations where we have not quantified the model bias explicitly, we have applied the global mean modelled:observed ratio.

Globally, wheat, soybean and cotton are the most sensitive of the crops to ozone damage. Relative yield loss values for wheat range from $1.2(1.5)$ (standard model ozone metric (bias corrected metric)) to $5.8(6.2) \%$, AOT40 producing the largest. Relative yield losses for soybean range from 2.6 (2.9) to 10.5 (11.4)\% with M12 giving the largest. For cotton we only present yield losses based on AOT40, which show a global value of $11.2(12.0) \%$. Rice and maize demonstrate higher tolerance to ozone exposure, with yield losses of around $0.9(0.9)$ to $1.4(1.4) \%$ for rice and $0.04(0.06)$ to 3.4 (3.7) \% for maize. Potato yield losses are 1.9 (2.0) \% globally, based upon AOT40.
A comparison with a previous studies (Van Dingenen et al., 2009; Averny et al., 2011a) shows our results produce a similar pattern of global relative yield losses for wheat, rice, maize and soybean (cotton and potato are not considered in Van Dingenen et al., 2009) with wheat and soybean being the most sensitive crops to ozone exposure. Van Dingenen et al. (2009) also demonstrate largest relative yield losses produced from AOT40 values for wheat, and M12 producing the largest relative yield losses for soybean. Our yield loss values for wheat (1.2 (1.5) to $5.8(6.2) \%)$ and soybean (2.6 (2.9) to $10.5(11.4) \%$ ) are smaller than those shown in Van Dingenen et al. (2009) which were 7.3 to $12.3 \%$ for wheat and 5.4 to $15.6 \%$ for soybean. We also show smaller yield losses when compared to the findings of Averny et al. (2011a) which show wheat relative yield losses of 3.9 to $15.4 \%$ and soybean relative yield losses of 8.5 to $13.9 \%$. The relative yield losses for rice and maize $(0.9(0.9) \%$ to $1.4(1.4) \%$ and $0.04(0.06) \%$ to 3.4 (3.7) \%, respectively) are also smaller here than those of Van Dingenen et al. (2009) ( 2.8 to $3.7 \%$ for rice and 2.4 to $4.1 \%$ for maize) and Averny et al. (2011a) (2.2 to $5.5 \%$ for maize with rice not investigated). Van Dingenen et al. (2009) and Averny et al. (2011a) both use data from the United States Department of 

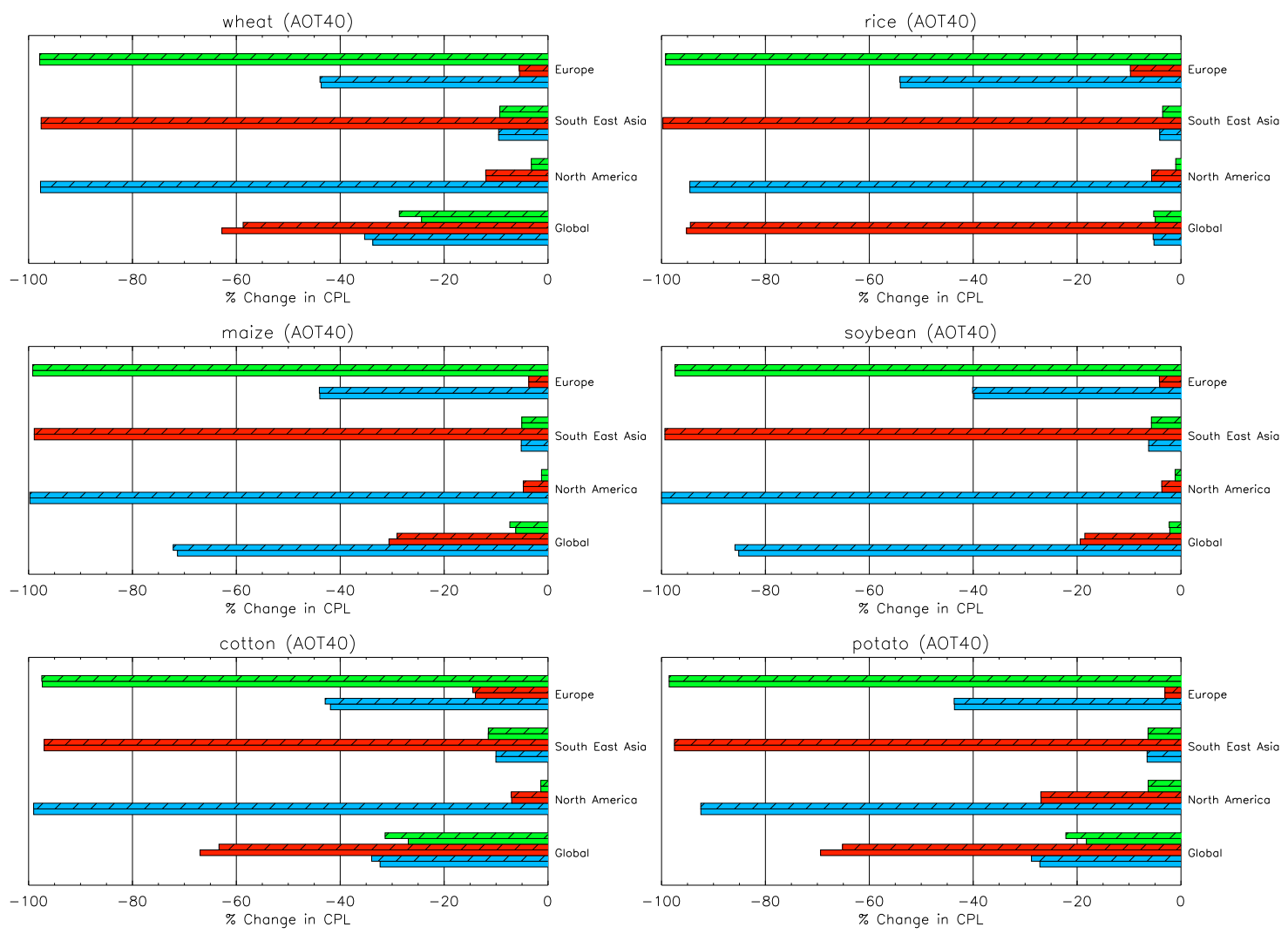

Fig. 10. Percentage reductions in ozone-induced crop production loss for the 6 crops considered (based upon the AOT40 exposure index) resulting from $100 \%$ regional cuts in anthropogenic $\mathrm{NO}_{\mathrm{x}}$ emissions. The y-axis shows the receptor regions, and coloured bars indicate the impacts from emission cuts applied in each region compared to the control model (Green = European emission cut, Red = SE Asia emission cut and Blue $=\mathrm{N}$ America emission cut). Solid colour bars show results based on the standard model metric and hatched bars show results based on the bias-corrected model metric (see main text for details).
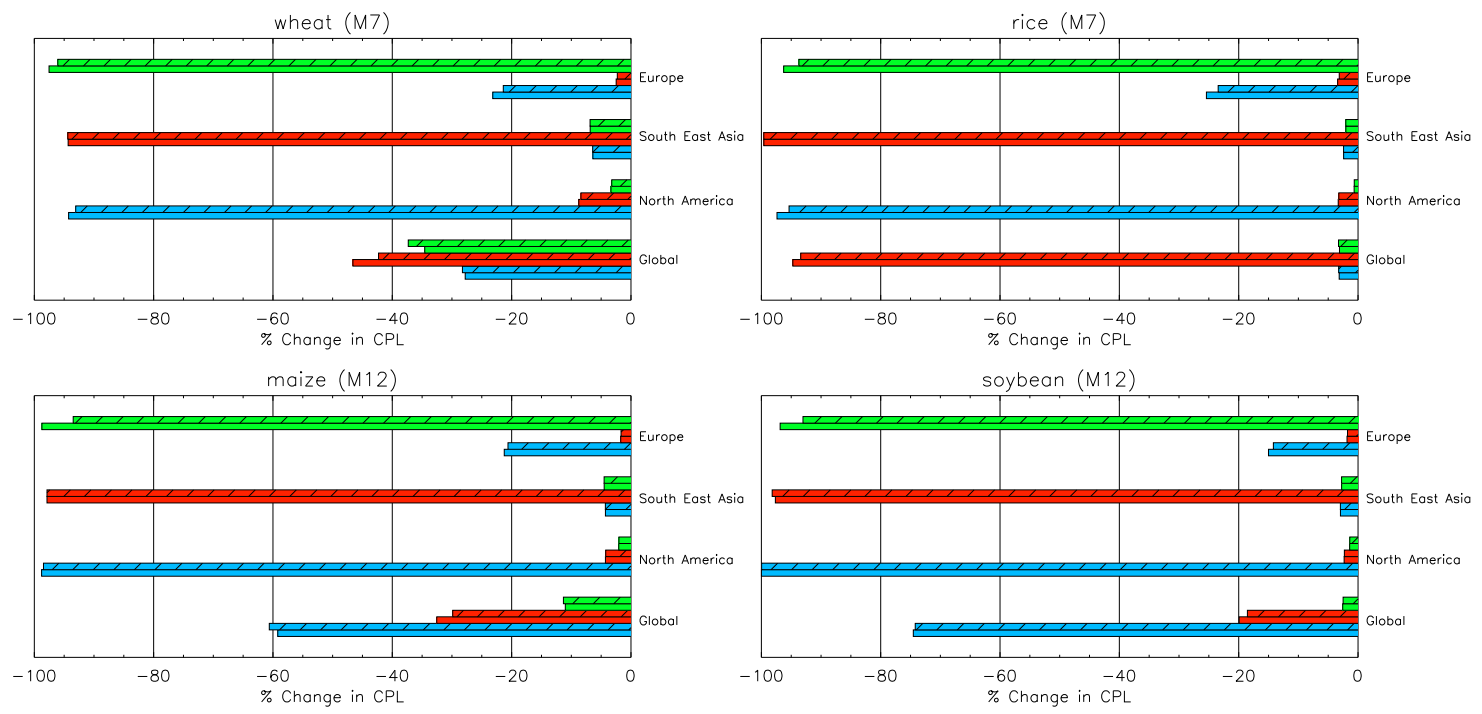

Fig. 11. As Figure 10, but using the M7 and M12 metrics for 4 of the crops. 

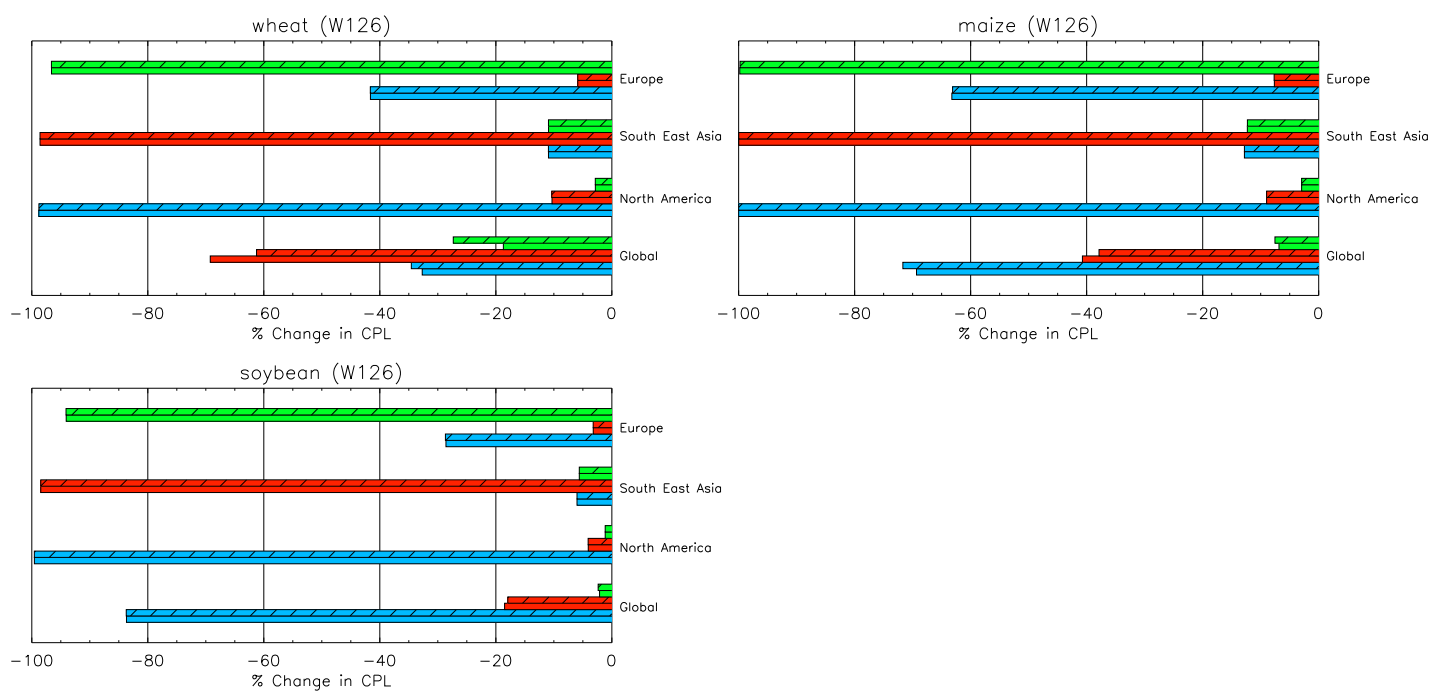

Fig. 12. As Figure 10, but using the W126 metric for 3 of the crops.

Agriculture (USDA) to define the growing seasons. In addition, the surface ozone distributions produced from the different CTMs used are likely somewhat different. Nevertheless, our control scenario produces comparable magnitudes of yield losses to those described previously, including those presented using similar bias-correction.

Table 4 also shows the regionally-aggregated relative yield losses for the three individual regions. For rice and soybean, relative losses tend to be highest over $\mathrm{N}$ America (up to 15.1 (16.3) \% for soybean and 3.2 (3.4) \% for rice). For wheat and potato the relative losses are largest over SE Asia with losses of up to 10.5 (10.4) \% for wheat and 4.5 (4.4) \% for potato. For maize, relative yield losses based on M12 and W126 are highest over SE Asia (0.07 (0.08) \% to 4.5(4.5) \%) with relative yield losses based on AOT40 highest over N America (3.5 (3.7) \%). Finally for cotton, highest yield losses are seen over N America with relative yield loss values of 16.1 (17.1) \% . These regional relative yield losses are a function of the geographical locations of the crops, the amount of yield produced for each crop over each region, and the geographical pattern of elevated ozone.

\subsection{Impact of regional cuts in $\mathrm{NO}_{\mathrm{x}}$ emissions on ozone induced CPL}

The impact of regional reductions in $\mathrm{NO}_{\mathrm{x}}$ emissions on regionally-aggregated ozone-induced CPL calculated from AOT40 exposure is shown in Fig. 10 for six crop types for both standard model and bias-corrected ozone metrics. Figure 11 shows the impact on CPL for 4 of the 6 crop types based on Mx (using the M7 index for wheat and rice and the M12 index for maize and soybean) and Fig. 12 shows the impact on CPL for 3 of the crops (wheat, maize and soybean) based on W126. Globally, $\mathrm{N}$ American $\mathrm{NO}_{\mathrm{x}}$ emission reductions result in largest changes to CPL for soybean and maize (59.2-85.1\% (60.6-85.9\% bias corrected)). SE Asian $\mathrm{NO}_{\mathrm{x}}$ emission reductions result in largest changes to wheat, rice, cotton and potato CPL (46.6-95.2\% (42.3-94.4\% bias corrected)). This primarily reflects the geographical distributions of these six crops and their yield distributions. Local reductions in $\mathrm{NO}_{\mathrm{x}}$ emissions result in near $100 \%$ reduction in ozone-induced CPL over each of the regions, demonstrating that local emission controls and air pollution strategies could effectively mitigate ozone-induced production losses. However, ozone-related CPL for rice and potato grown in $\mathrm{N}$ America cannot be completely eliminated through local emissions reductions. This is shown for both the original and bias corrected model results.

In the European region, production losses are reduced by $15.0-63.2 \%$ (14.2-63.1\% bias corrected) when cutting $\mathrm{N}$ American $\mathrm{NO}_{\mathrm{x}}$ emissions. Maize CPL (based on W126) shows the most sensitivity to N American emissions (63.2\% (63.1\% bias corrected)) with cotton CPL (when based on AOT40) showing the greatest sensitivity to SE Asian $\mathrm{NO}_{\mathrm{x}}$ sources (14.0\% (14.5\% bias corrected)). Soybean (based on M12) shows the lowest sensitivity to N American (15.0\% (14.2\% bias corrected)) emissions with maize (based on M12) showing the lowest sensitivity to SE Asian (1.71\% ( $1.67 \%$ bias corrected)) emissions. When diagnosing the impact of emissions reductions it is shown for each individual metric that the impact of $\mathrm{N}$ American Emissions on European CPL is the largest intercontinental transboundary effect in this study. Figures 10,11 and 12 show that the minimum reduction in European CPL from N American emission cuts is larger than both the maximum European emissions impact on SE Asia and the SE Asian emission impact on N America. Over N America, the largest non-local impact on CPL results from $\mathrm{SE}$ Asian $\mathrm{NO}_{\mathrm{x}}$, with $\mathrm{CPL}$ reductions ranging 
from $26.95 \%$ (based on AOT40) for potato (26.98\% bias corrected) to $2.33 \%$ (based on M12) for soybean $(2.29 \%$ bias corrected). N American CPL reductions of 0.65-6.31\% (0.63-6.32\% bias corrected) result from reductions in European $\mathrm{NO}_{\mathrm{x}}$, with potato and wheat showing the largest sensitivities. On the whole, CPL of all six crops over SE Asia are reduced by approximately equal amounts as a result of $\mathrm{N}$ American and European emissions reductions. Cotton CPL show the greatest difference, with European emissions cuts producing a reduction in CPL of $11.5 \%(11.4 \%$ bias corrected) compared with a reduction of $10.0 \%$ (10.0\% bias corrected) produced by $\mathrm{N}$ American emissions cuts.

Overall, the results exhibit that the inclusion of model bias correction does not have a significant effect on the transboundary effects deduced. When the bias corrected results are considered $\mathrm{N}$ American $\mathrm{NO}_{\mathrm{x}}$ emissions still produce the largest non-local impact in this study resulting in CPL reductions over Europe of 14.2-63.2\% (range over all crops and metrics accounting for bias correction).

\subsection{Impact of regional cuts in $\mathrm{NO}_{\mathrm{x}}$ emissions on crop production}

Figure 13 shows the estimated changes in crop production under each of the emissions reduction scenarios for the standard and bias-corrected model metrics. These are the mean changes in production from all metrics considered for each of the crops (AOT40, MX and W126 for wheat, maize and soybean; AOT40 and MX for rice; and AOT40 only for cotton and potato).

$\mathrm{N}$ American anthropogenic $\mathrm{NO}_{\mathrm{x}}$ emission reductions lead to the greatest increase in global production for both maize and soybean with increases of $8.0 \mathrm{Mt}$ and $9.7 \mathrm{Mt}$ shown respectively (8.8 Mt and 10.6 Mt bias corrected). Reductions to SE Asian emissions result in the greatest increase in production for wheat, rice, cotton and potato. Under SE Asian emissions cuts wheat and rice show the largest sensitivities, with increases in production of $6.7 \mathrm{Mt}$ and $11.6 \mathrm{Mt}$ respectively (6.6 Mt and 11.9 Mt bias corrected).

When shown in terms of increases in crop production, the impact of $\mathrm{N}$ American $\mathrm{NO}_{\mathrm{x}}$ emissions on Europe are still shown to produce the largest transboundary effect in this study. Over Europe, local emissions cuts result in increases in production which range from $0.02 \mathrm{Mt}(0.03 \mathrm{Mt}$ bias corrected) for rice to $2.4 \mathrm{Mt}$ (3.5 Mt bias corrected) for wheat. $\mathrm{N}$ American emissions reductions result in increases in production over Europe of $0.008-0.8 \mathrm{Mt}$ (0.01-1.2 Mt bias corrected) with rice showing the smallest sensitivity and wheat showing the greatest. This represents 33.3-40.0\% (33.3$35.3 \%$ bias corrected) of the increase in production attainable from local emissions cuts. Over $\mathrm{N}$ America, local $\mathrm{NO}_{\mathrm{x}}$ reductions result in an increase in production of 0.04 9.15 Mt (0.04-10.0 Mt bias corrected), with rice showing the smallest sensitivity and soybean showing the largest. The largest non-local contribution to production increases is the cut in SE Asian emissions, resulting in increases in production of $0.002-0.39 \mathrm{Mt}(0.002-0.43 \mathrm{Mt}$ bias corrected). This represents $4.3-5.0 \%(4.3-5.0 \%$ bias corrected) the increase in production from local emissions cuts. Over SE Asia, $\mathrm{N}$ American emissions reductions result in an increase in production of 0.09-1.1 Mt (0.09-1.2 Mt bias corrected) with European emissions cuts also producing increases in production that fall within a similar range of $0.08-1.1 \mathrm{Mt}(0.08-1.2 \mathrm{Mt}$ bias corrected). These represent 4.2-8.9\% (4.2-9.6\% bias corrected) and 3.8-8.9\% (3.8-9.6\% bias corrected) respectively of the impact of a reduction in local emissions (2.112.4 Mt (2.1-12.5 Mt bias corrected)).

Overall, on both a regional and global scale, increases in production are greatest for wheat, maize and soybean which are 3 of the most widely grown crops in the world (Fig. 1), with wheat production benefitting greatly from reductions in $\mathrm{SE}$ Asian $\mathrm{NO}_{\mathrm{x}}$ emission reductions and maize and soybean tending to benefit from reductions in $\mathrm{N}$ American emissions. The results also show that the inclusion of model bias correction introduces a range of $-1.8-60.2 \%$ difference to the increases in production estimated under each emissions scenario. However, even within this uncertainty, the reduction in $\mathrm{N}$ American emissions still produces the largest non-local increase in crop production over Europe when compared to the estimated impacts of local European emission reductions.

\section{Discussion}

Using the 4 metrics (AOT40,M7,M12,W126), model calculations show that for 4 of the major crops considered (wheat, rice, cotton and potato) reductions in $\mathrm{SE}$ Asian $\mathrm{NO}_{\mathrm{x}}$ emissions tend to produce the greatest reduction in crop production losses on a global scale. These correspond to an estimated increase in crop production of 3.7 to $11.6 \mathrm{Mt}$ (3.7 to 11.9 Mt bias corrected). Cuts to $\mathrm{N}$ American emissions result in the greatest global impact on crop production losses for maize and soybean, producing an estimated increase in crop production of 8.0 to $9.7 \mathrm{Mt}(8.8$ to $10.6 \mathrm{Mt}$ bias corrected). The changes in CPL based on Mx show a similar pattern to those calculated using the AOT40 and W126 indices, however they are much smaller. Figure 3 shows that under control emissions, modelled mean monthly surface ozone is slightly above the $40 \mathrm{ppbv}$ threshold of AOT40, particularly over Europe, SW USA and SE Asia. Under emission reduction scenarios, small reductions in ozone resulting in concentrations falling below $40 \mathrm{ppbv}$ can produce a relatively large decrease in AOT40. Due to the linear relationship of yield loss with AOT40, this produces a comparable relative change in yield. The change in Mx however, is directly related to the fractional change in mean background ozone, which may be smaller than the respective change in AOT40 where ozone is near to $40 \mathrm{ppbv}$. Due to the Weibull relationship between Mx and relative yield loss (Table 2), a given change in $\mathrm{Mx}$ also produces smaller changes in relative yield loss. $\mathrm{N}$ American 

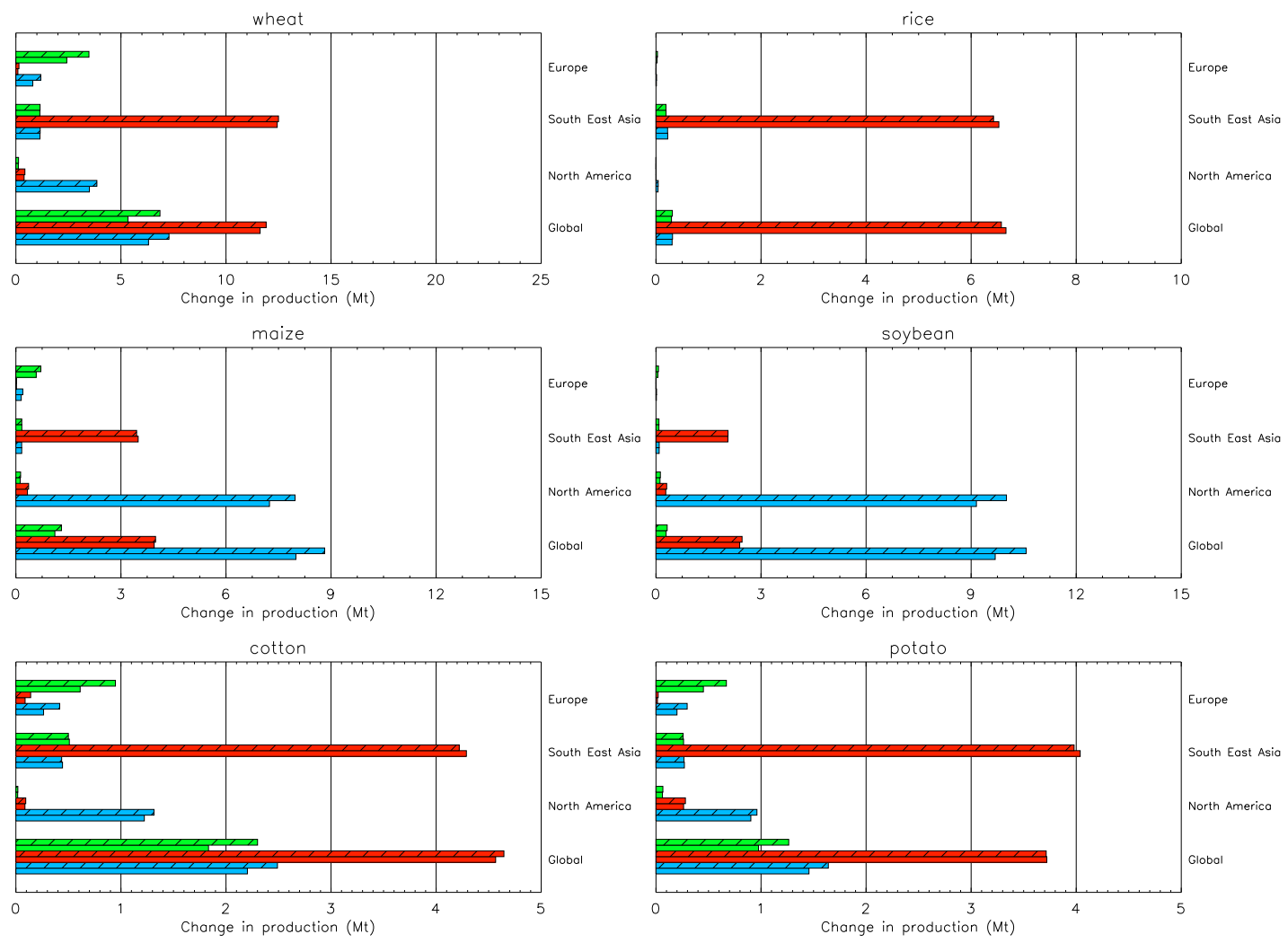

Fig. 13. Projected increase in crop production (in million metric tons(Mt)) for the 6 crops resulting from $100 \%$ regional cuts in anthropogenic $\mathrm{NO}_{\mathrm{x}}$ emissions. The $\mathrm{y}$-axis shows the receptor regions, and coloured bars indicate the average impacts based on AOT40, Mx and W126 metrics from emission cuts applied in each region compared to the control model (Green = European emission cut, Red = SE Asia emission cut and Blue $=\mathrm{N}$ America emission cut). Solid colour bars show results based on the standard model metric and hatched bars show results based on the bias-corrected model metric (see main text for details).

$\mathrm{NO}_{\mathrm{x}}$ emissions produce the largest intercontinental ozone impact in this study. This is consistent with previous studies that have shown trans-Atlantic transport of ozone and its precursors to be more efficient compared with trans-Pacific and trans-Siberian transport (Stohl, 2001).

The results demonstrate that local air quality and emissions control strategies over each of the regions have the potential to effectively mitigate ozone-induced production losses for six major crop types. A $100 \%$ reduction in local anthropogenic $\mathrm{NO}_{\mathrm{x}}$ emissions results in near $100 \%$ reductions in AOT40 derived crop production losses for wheat, rice, maize, soybean, cotton and potato in each of the regions. In $\mathrm{N}$ America, a $100 \%$ reduction in local anthropogenic $\mathrm{NO}_{\mathrm{x}}$ produces a $94.5 \%$ ( $94.6 \%$ bias corrected) reduction in local rice production losses and a $92.4 \%(92.4 \%$ bias corrected) reduction in potato production losses. This indicates a smaller sensitivity of $40 \mathrm{ppbv}$ exeedences over potato and rice growing regions to local anthropogenic emissions compared to Europe and SE Asia. Figure 1 shows that the majority of $\mathrm{N}$ American potato growing regions are in north and western USA. The greatest potato production output is over the north west of the N American region. Rice growing is located over the south east of the region and a small area along the west coast. The production data shows higher output of rice to the west. Jaffe (2011) recently showed that for the period 1995-2009, biomass burning emissions through the summer are significantly correlated with the number of days where surface ozone exceeds AQS guideline levels in the western United States. This indicates that biomass burning emissions are likely playing a role in controlling the exposure of crops to ozone in this region. It can be seen in Fig. 2 that under $\mathrm{N}$ American emissions reductions, there are still parts of the $\mathrm{N}$ American domain (over western Canada) where biomass burning $\mathrm{NO}_{\mathrm{x}}$ emissions of reasonable magnitude remain. These remaining emissions could still lead to exceedances of the 40ppbv threshold of AOT40.

As discussed above, the threshold nature of the AOT40 index means that it is sensitive to small ozone concentration changes around $40 \mathrm{ppbv}$. Contributions of a few ppbv to surface ozone from non-local emissions therefore have the potential to significantly alter the AOT40 exposure of crops. This also results in a large sensitivity to errors in the model surface ozone distribution, and consequent uncertainty in the AOT40-derived production losses (Tuovinen et al., 2007). 


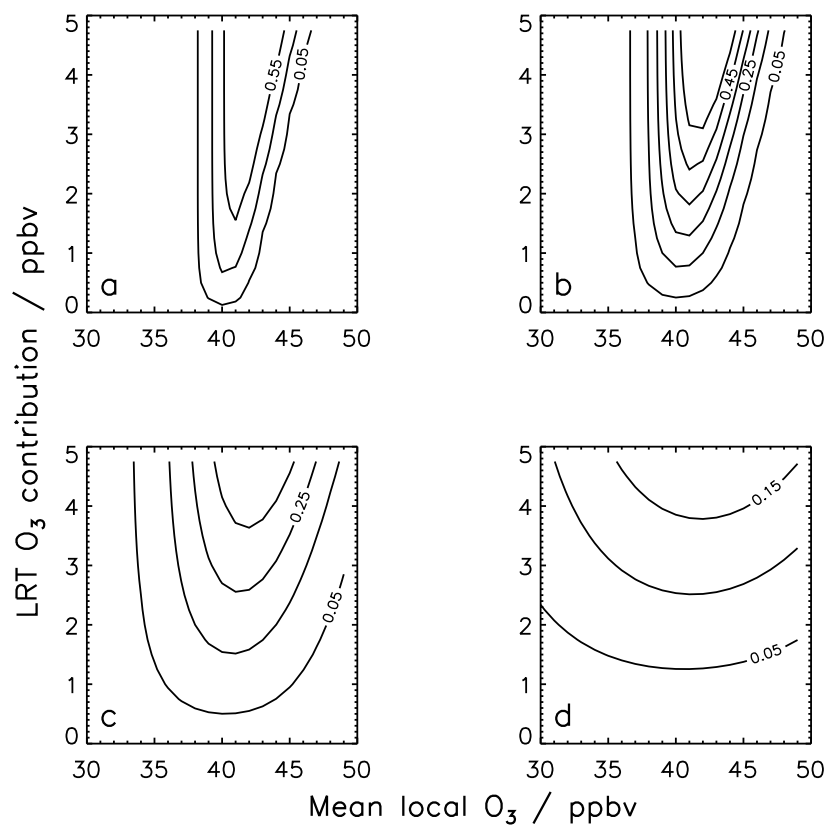

Fig. 14. Fractional change in AOT40 due to long-range transport (LRT) as a function of mean local ozone and LRT ozone contribution. Panels (a-d) are based on normally-distributed local ozone distributions, with standard deviations of (a) 1 ppbv, (b) 2 ppbv, (c) 4 ppbv and (d) 10 ppbv. The LRT contribution is assumed to uniformly translate the local ozone distribution across all concentrations. AOT40 is assumed proportional to the fraction of distribution concentrations exceeding $40 \mathrm{ppbv}$.

Our inclusion of bias-corrected calculations allows us to account for the impact of such uncertainty on our results. The present-day sensitivities of AOT40-derived yield loss to nonlocal emissions are a function of not only the non-local ozone precursor emissions themselves, but also the local ozone abundance. In more general terms, the threshold nature of the AOT40 metric results in long-range transport contributions to yield loss being strongly dependent on local ozone concentrations. Figure 14 shows calculations of the change in AOT40 as a function of mean local ozone concentration and the ozone contribution from long-range transport, assuming a normal distribution of local ozone concentrations. Maximum sensitivity of AOT40 to non-local ozone is seen where the mean local ozone is close to $40 \mathrm{ppbv}$. In addition, a relatively small variability in local ozone around $40 \mathrm{ppbv}$ increases this sensitivity. This highlights the problem of using a threshold metric to assess contributions of different ozone sources to local yield loss. Under future emission and climate scenarios, where surface ozone concentrations may be larger in many regions, the AOT40-derived yield-loss response to non-local emission reductions may be reduced, if such reductions are not sufficient to bring ozone concentrations below the 40 ppbv threshold. Alternatively, under a scenario where local emissions in Europe and $\mathrm{N}$ America are reduced, but

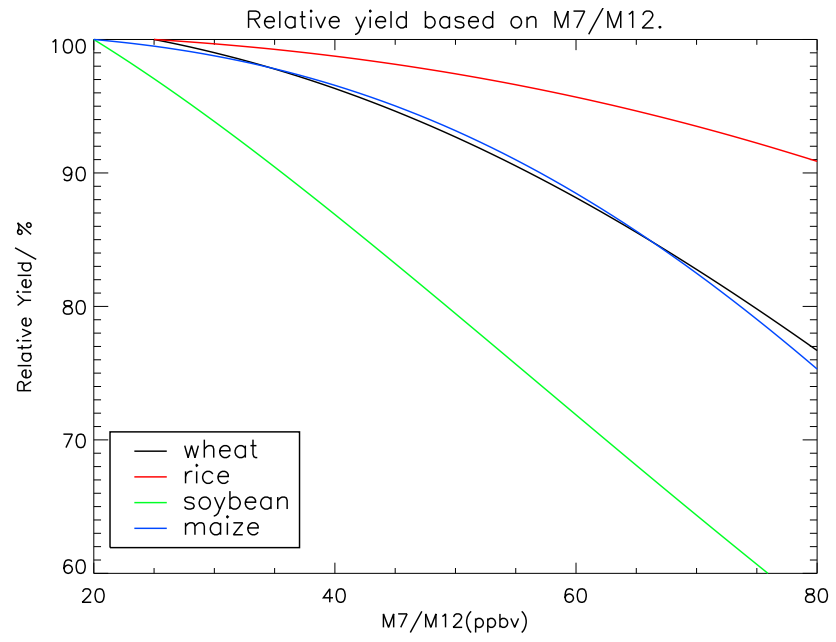

Fig. 15. Relative yield as a function of M7/M12 for wheat, rice, maize and soybean. The equations for these functions are shown in Table 2.

an increase in background ozone concentrations is driven by increasing Asian emissions (e.g. Jacob et al., 1999), the sensitivity of European and N American AOT40 yield-loss to Asian emission reductions may increase.

Since relative yield loss is linearly related to AOT40 (Mills et al., 2007), the reduction in yield loss under the emissions cut scenarios changes proportionally with the magnitude of a change in AOT40. Assuming that under each of the emission scenarios, ozone remains greater than $40 \mathrm{ppbv}$, this leads to a linear relationship between ozone reduction and yield loss reduction, which is independent of the absolute ozone concentration. For the concentration based indices $\mathrm{Mx}$, yield loss reductions depend on the magnitude of the absolute ozone concentration, in addition to the ozone change. This is due to the non-linear Weibull relationship between yield loss and Mx (shown in Fig. 15), which is also dependent on the sensitivity of each crop to ozone exposure. With the exception of soybean, at larger background ozone concentrations (and hence higher Mx), a given change in the mean background ozone concentration would result in a greater response of yield reduction for each crop, than at smaller background ozone concentrations. This behaviour means that the $\mathrm{Mx}$ indices can mimic a threshold response, similar to that of AOT40. This behaviour also means that under increased background ozone, the relative yield loss changes produced under the respective emissions cut scenarios would be more pronounced, and thus the impact on crop production would be more pronounced.

The results of this study only consider crop production losses that are related to ozone exposure. In reality, there are many other drivers that can cause a reduction in crop yields. These factors include exposure to higher temperatures under a warmer climate, drought stress, and whether the crops are properly irrigated. It is shown by Liu et al. (2010), that for a 
winter wheat-summer maize cropping system in the HuangHuai-Hai Plain of China, a $5^{\circ} \mathrm{C}$ increase in temperature results in an overall yield reduction of $-18.5 \pm 22.8 \%$. They also present an overall yield reduction of $-2.3 \pm 13.2 \%$ for temperature rise of $2{ }^{\circ} \mathrm{C}$. By comparison, the results presented here show that for the SE Asia region (which contains China), for wheat, regionally-aggregated relative yield losses due to ozone exposure are 2.4 to $10.5 \%$ (2.7 to $10.4 \%$ bias corrected) (Table 4), showing that ozone-induced crop damage under control emissions for 2000 is similar in magnitude to that caused by $2{ }^{\circ} \mathrm{C}$ temperature rise and up to roughly half of that of a $5{ }^{\circ} \mathrm{C}$ temperature rise. For maize, the effect of ozone damage over SE Asia is less, with relative yield losses of 0.07 to $4.5 \%$ ( 0.08 to $4.5 \%$ bias corrected).

An additional factor to consider is the possible benefits to crop yields under future climate due to fertilization from enhanced $\mathrm{CO}_{2}$, which can act to increase the biomass of crops (Franzaring et al., 2008). This could offset yield losses through rising ozone or temperatures. The location of crop cultivation, the extent of crop irrigation and the management of the crops are also important factors. It has also been shown in a recent study that ozone damage to plants can feed back on yield loss through the effect on evapotranspiration. Bernacchi et al. (2011) showed that ozone exposure of soybean can reduce water use by as much as $15 \%$, resulting in increased sensible heat flux which is indicative of a day-time increase in canopy temperature of up to $0.7^{\circ} \mathrm{C}$, with warmer temperatures leading to further reduction in crop yields (Liu et al., 2010). With a rise in surface ozone coupled with a warmer climate, the impact on crop yields due to ozoneinduced production loss may act to enhance the yield loss observed for crops due to the warmer temperatures. However, it should be noted that these yield-limiting factors interact in non-linear ways depending on whether warmer temperatures limit ozone uptake and hence the damage caused. The transboundary impact of ozone and its precursor emissions on yields highlight that even non-local emission reduction strategies could at least partially offset a reduction in crop yields under a warmer future climate. These interactions all play important roles in determining how climate change and emission changes may affect crop yields.

Bias correction of our results to account for model error, introduces a range of uncertainty into the crop production response under each emissions cut scenario. For example, the impact of N American emission cuts on global soybean production produces a difference of up to $0.9 \mathrm{Mt}$ between the control model results (a $9.7 \mathrm{Mt}$ increase in production) and the bias-corrected results (a 10.6 Mt increase in production). Bias correction of results for the impact of European emissions cuts on global wheat production also produces a difference of about $1.5 \mathrm{Mt}$. This demonstrates that model error can produce up to $1.5 \mathrm{Mt}$ difference in the estimated impacts on crop production from regional anthropogenic $\mathrm{NO}_{\mathrm{x}}$ emission cuts. However, our results also show that the estimated transboundary effects are much more robust to model error, with little difference when accounting for model bias correction compared to the control model metrics. The impact of $\mathrm{N}$ American $\mathrm{NO}_{\mathrm{x}}$ on European crop production produces the largest transboundary effect for both the bias-corrected and standard model results. We therefore have high confidence in the relative importance of the transboundary effects shown in this study.

An additional source of uncertainty in our results is that the indices used (AOT40,Mx,W126) have not been designed with the specific purposes of estimating yield losses due to the intercontinental transport of ozone. The exposure response functions used are based on data collected from cultivars of crops grown in N America and Europe. They therefore may not adequately represent the sensitivities of crops grown over Asia to ozone exposure, which may differ in ozone sensitivity to those grown over Europe and N America. These indices were also developed in regions where, at the time, concern was placed on peak ozone concentrations (Heck and Colwing, 1997). Since their development, regional ozone distributions have changed, due to declining ozone precursor emissions over N America and Europe, and rising emissions over East Asia, changing contributions to background NH ozone (Cooper et al., 2010; Jacob et al., 1999). This shift has resulted in less episodic high ozone events, but an increase in background ozone concentrations over Europe and $\mathrm{N}$ America. This may result in different exposure regimes of crops to ozone and hence the resultant impact on crop production.

\section{Conclusions}

This study is the first to estimate the impact of ozone precursor emissions from each of the Northern Hemisphere's major industrialized regions (N America, SE Asia, and Europe) on crop yields globally and in continents downwind of each region. We have made the first estimates of the impact of intercontinental transboundary pollution on crop yields, using a range of available metrics applied in a standardized manner.

We have shown that for 4 of the crops considered (wheat, rice, cotton and potato), reductions in SE Asian anthropogenic $\mathrm{NO}_{\mathrm{x}}$ emissions are predicted to produce the greatest reduction in global crop production losses (46.6 to $95.2 \%$ (42.3 to $94.4 \%$ bias corrected)), based on AOT40, Mx and W126 metrics. This corresponds to an estimated increase in crop production of 3.7 to $11.6 \mathrm{Mt}$ (3.7 to $11.9 \mathrm{Mt}$ bias corrected). Cuts to $\mathrm{N}$ American emissions result in the greatest global impact on crop yield reductions for maize and soybean (59.2 to $85.1 \%$ (60.6 to $85.9 \%$ ) bias corrected). This results in an estimated increase in crop production of 8.0 to $9.7 \mathrm{Mt}$ ( 8.8 to $10.6 \mathrm{Mt}$ bias corrected). Our model calculations suggest that reductions in anthropogenic $\mathrm{NO}_{\mathrm{x}}$ emissions from $\mathrm{N}$ America give the largest non-local effect, resulting in European production loss reductions of between $15.0 \%$ and $63.2 \%$ (14.2-63.1\% bias corrected), for a $100 \%$ emissions 
cut. The impact on absolute crop production also shows that a reduction in $\mathrm{N}$ American $\mathrm{NO}_{\mathrm{x}}$ emissions results in the greatest non-local contribution to production increases, enhancing production over Europe by approximately one third of the production increase produced by the local European emission cut for wheat. These results demonstrate that local air quality and emission control strategies have the potential to partly alleviate ozone-induced crop production loss in continents downstream, in addition to effectively mitigating local ozone-induced yield losses. It also indicates that for three of the world's most widely grown crops (wheat, maize and soybean) local air quality strategies can significantly benefit crop production output.

Finally, we have shown that quantification of the transboundary effects on crop yield loses due to long-range transport of ozone and precursors differs depending on the ozone damage metric used, and for threshold-based indices such as AOT40, the inferred long-range transport contribution shows a strong dependence on the local ozone concentration distribution. Nevertheless, our conclusions regarding the relative importance of the different regions in controlling crop production losses downstream are robust across the range of metrics used. This study could be extended to incorporate flux-response relationships to assess the effect of long range transport of ozone and its precursors on crops. Flux based methods consider the flux of ozone into the plant, mainly through the stomata, and can begin to account for modifying environmental conditions and hence could be more applicable in different global regions and future climates (Harmens et al., 2007). However, at present flux-response relationships are only available for wheat, potato and tomato (Pleijel et al., 2004; Mills et al., 2011a), and these have not been parameterised for global application.

\section{Supplement related to this article is available online at: http://www.biogeosciences.net/9/271/2012/ bg-9-271-2012-supplement.pdf.}

Acknowledgements. The authors wish to acknowledge the World data centre for Greenhouse Gases (WDCGG), the Japanese Meteorological Agency, BMKG and EMPA, ISAC and PolyU for provision of data over SE Asia as well as the EMEP and CASTNET networks for providing data over Europe and N America, respectively. This work was supported with funding from the UK Natural Environment Research Council (NERC) and the UK Met Office as a CASE studentship.

Edited by: A. Arneth

\section{References}

Adams, R., Crocker, T., and Thanavibulchai., N.: An economic assessment of air pollution damages to selected annual crops in southern California, J. Environ. Econom. Manage., 9, 42-58, 1982.

Arnold, S. R., Chipperfield, M., and Blitz, M.: A three-dimensional model study of the effect of new temperature-dependent quantum yields for acetone photolysis, Geophys. Res.-Atmos., 110, D22305, doi:10.1029/2005JD005998, 2005.

Ashmore, M.: Assessing the future global impacts of ozone on vegetation, Plant Cell Environ., 28, 949-964, 2005.

Aunan, K., Bernsten, T., and Seip, H.: Surface Ozone in China and its possible impact on agricultural crop yields, Ambio, 29, 294 301, 2000.

Averny, S., Mauzerall, D., Liu, J., and Horowitz, L.: Global crop yield reductions due to surface ozone exposure: 1. Year 2000 crop production losses and economic damage, Atmos. Environ., 45, 2284-2296, doi:10.1016/j.atmosenv.2011.01.045, 2011a.

Averny, S., Mauzerall, D., Liu, J., and Horowitz, L.: Global crop yield reductions due to surface ozone exposure: 2. Year 2030 potential cro production losses and economic damage under two scenarios of $\mathrm{O}_{3}$ pollution, Atmos. Environ., 45, 2297-2309, doi:10.1016/j.atmosenv.2011.01.00, 2011 b.

Bernacchi, C., Leakey, A., Kimball, B., and Ort, D.: Growth of soybean at future tropospheric ozone concentrations decreases canopy evapotranspiration and soil water depletion, Environ. Pollut., 159, 1464-1472, 2011.

Chipperfield, M. P.: New version of the TOMCAT/SLIMCAT offline chemical transport model: Intercomparison of stratospheric tracer experiments, Q. J. Roy. Meteorol. Soc., 132, 1179-1203, 2006.

Cooper, O. R., Parrish, D. D., Stohl, A., Trainer, M., Nedelec, P., Thouret, V., Cammas, J. P., Oltmans, S. J., Johnson, B. J., Tarasick, D., Leblanc, T., McDermid, I. S., Jaffe, D., Gao, R., Stith, J., Ryerson, T., Aikin, K., Campos, T., Weinheimer, A., and Avery, M. A.: Increasing springtime ozone mixing ratios in the free troposphere over western North America, Nature, 463, 344-348, 2010.

Crutzen, P., Lawrence, M., and Pöschl, U.: On the background photochemistry of tropospheric ozone, Tellus A - Dynam. Meteorol Oceanogr., 51, 123-146, 1999.

Dentener, F., Keating, T., and Akimoto, H. (eds.): Hemispheric transport of air pollution. Part A: Ozone and particulate matter, economic Commission For Europe, United Nations, Geneva, 2010.

Derwent, R., Stevenson, D., Collins, W., and Johnson, C.: Intercontinental transport and the origins of the ozone observed at surface sites in Europe, Atmos. Environ., 38, 1891-1901, 2004.

Duncan, B. and Bey, I.: A modeling study of the export pathways of pollution from Europe: Seasonal and interannual variations (1987-1997), Journal of Geophys. Res.-Atmos., 109, D08301, doi:10.1029/2003JD004079, 2004.

EEA: Environmental assessment Report No. 2, Environment in the European Union at the turn of the century, European Environment Agency, Copenhagen, 446 pp., 1999.

Emberson, L. D., Bueker, P., Ashmore, M. R., Mills, G., Jackson, L. S., Agrawal, M., Atikuzzaman, M. D., Cinderby, S., Engardt, M., Jamir, C., Kobayashi, K., Oanh, N. T. K., Quadir, Q. F., and Wahid, A.: A comparison of North American and Asian 
exposure-response data for ozone effects on crop yields, Atmos. Environ., 43, 1945-1953, 2009.

Emmons, L. K., Walters, S., Hess, P. G., Lamarque, J.-F., Pfister, G. G., Fillmore, D., Granier, C., Guenther, A., Kinnison, D., Laepple, T., Orlando, J., Tie, X., Tyndall, G., Wiedinmyer, C., Baughcum, S. L., and Kloster, S.: Description and evaluation of the Model for Ozone and Related chemical Tracers, version 4 (MOZART-4), Geosci. Model Dev., 3, 43-67, doi:10.5194/gmd3-43-2010, 2010.

Federal Register: No. 60. National Ambient Air Quality Standards for Ozone, vol. 73, Federal Register, 27 March, 20081643616512, 2008.

Fiore, A. M., Dentener, F. J., Wild, O., Cuvelier, C., Schultz, M. G., Hess, P., Textor, C., Schulz, M., Doherty, R. M., Horowitz, L. W., MacKenzie, I. A., Sanderson, M. G., Shindell, D. T., Stevenson, D. S., Szopa, S., Van Dingenen, R., Zeng, G., Atherton, C., Bergmann, D., Bey, I., Carmichael, G., Collins, W. J., Duncan, B. N., Faluvegi, G., Folberth, G., Gauss, M., Gong, S., Hauglustaine, D., Holloway, T., Isaksen, I. S. A., Jacob, D. J., Jonson, J. E., Kaminski, J. W., Keating, T. J., Lupu, A., Marmer, E., Montanaro, V., Park, R. J., Pitari, G., Pringle, K. J., Pyle, J. A., Schroeder, S., Vivanco, M. G., Wind, P., Wojcik, G., $\mathrm{Wu}, \mathrm{S}$., and Zuber, A.: Multimodel estimates of intercontinental source-receptor relationships for ozone pollution, J. Geophys. Res.-Atmos., 114, D04301, doi:10.1029/2008JD010816, 2009.

Fowler, D., Amann, M., Anderson, R., Ashmore, M., Cox, P., Depledge, M., Derwent, D., Grennfelt, P., Hewitt, N., Hov, O., Jenkin, M., Kelly, F., Liss, P., Pilling, M., Pyle, J., Slingo, J., and Stevenson, D. (eds.): Ground level ozone in the 21st Century: Future trends, impacts and policy implications., rS Policy Document 15/08, ISBN: 978-0-85403-713-1, 2008.

Franzaring, J., Hoegy, P., and Fangmeier, A.: Effects of free-air $\mathrm{CO} 2$ enrichment on the growth of summer oilseed rape (Brassica napus cv. Campino), Agr. Ecosyst. Environ., 128, 127-134, 2008.

Fuhrer, J.: Ozone risk for crops and pastures in present and future climates, Naturwissenschaften, 96, 173-194, 2009.

Fuhrer, J. and Achermann, B.: Critical Levels for Ozone: A UNECE Workshop Report., in: Critical Levels for Ozone: A UNECE Workshop Report., Liebefeld-Bern, Switzerland. Nr. 16, 1994.

Giannakopoulos, C., Chipperfield, T. P., Law, K. S., and Pyle, J. A.: Validation and intercomparison of wet and dry deposition schemes using $\mathrm{Pb}-210$ in a global three-dimensional off-line chemical transport model, J. Geophys. Res.-Atmos., 104, 2376123784, 1999.

Harmens, H., Mills, G., Emberson, L. D., and Ashmore, M. R.: Implications of climate change for the stomatal flux of ozone: A case study for winter wheat, Environ. Pollut., 146, 763-770, 2007.

Heagle, A. S.: Ozone and Crop Yield, Ann. Rev. Phytopathol., 27, 397-423, 1989.

Heck, W. and Colwing, E.: The need for a long term cumulative secondary ozone standard - an ecological perspective, Environmental Manager January, 1997.

Heck, W., Cure, W., Rawlings, J., Zaragoza, L., Heagle, A., Heggestad, H., Kohut, R., Kress, L., and Temple, P.: Assessing Impacts Of Ozone On Agricultural Crops .2. Crop Yield Functions And Alternative Exposure Statistics, J. Air Pollut. Contr.
Assoc., 34, 810-817, 1984.

Holland, M., Mills, G., Hayes, F., Buse, A., Emberson, L., Cambridge, H., Cinderby, S., Terry, A., and Ashmore, M.: Economic assessment of crop yield losses from ozone exposure. Report to UK Department of Environment, Food and Rural affairs under contract $1 / 2 / 170$, Centre for Ecology and Hydrology, Bangor, 2002.

Holstag, A. A. M. and Boville, B. A.: Local Versus Nonlocal Boundary-Layer Diffusion In A Global Climate Model, J. Climate, 6, 1825-1842, 1993.

Hudman, R., Jacob, D., Cooper, O., Evans, M., Heald, C., Park, R., Fehsenfeld, F., Flocke, F., Holloway, J., Hubler, G., Kita, K., Koike, M., Kondo, Y., Neuman, A., Nowak, J., Oltmans, S., Parrish, D., Roberts, J., and Ryerson, T.: Ozone production in transpacific Asian pollution plumes and implications for ozone air quality in California, J. Geophys. Res.-Atmos., 109, D23S10, doi:10.1029/2004JD004974, 2004.

Jacob, D., Logan, J., and Murti, P.: Effect of rising Asian emissions on surface ozone in the United States, Geophys. Res. Lett., 26, 2175-2178, 1999

Jaffe, D.: Relationship between Surface and Free Tropospheric Ozone in the Western U.S, Environ. Sci. Technol., 45, 432-438, 2011.

Jager, H., Unsworth, M., De Temmerman, L., and Mathy, P.: Effects of Air Pollutants on Agricultural Crops in Europe, results of the European Open-Top Chambers project, Air Pollut. Res., Report No. 46, 46, 1992.

Jager, H., Unsworth, M., De Temmerman, L., and Mathy, P.: Effects of Air Pollutants on Agricultural crops in Europe: results of the European Open-Top Chambers Project., Air Pollution Series of the Environmental Research Programme of the Commission of the European Communities, Directorate-General for Science, Research and Development, Brussels, Belgium, Report No. 46., 1996.

Lamarque, J. F., Bond, T. C., Eyring, V., Granier, C., Heil, A., Klimont, Z., Lee, D., Liousse, C., Mieville, A., Owen, B., Schultz, M. G., Shindell, D., Smith, S. J., Stehfest, E., Van Aardenne, J., Cooper, O. R., Kainuma, M., Mahowald, N., McConnell, J. R., Naik, V., Riahi, K., and van Vuuren, D. P.: Historical (1850-2000) gridded anthropogenic and biomass burning emissions of reactive gases and aerosols: methodology and application, Atmos. Chem. Phys., 10, 7017-7039, doi:10.5194/acp10-7017-2010, 2010

Li, X. S., He, Z. S., Fang, X. M., and Zhou, X. J.: Distribution of surface ozone concentration in the clean areas of China and its possible impact on crop yields, Adv. Atmos. Sci., 16, 154-158, 1999.

Lin, C. Y. C., Jacob, D. J., and Fiore, A. M.: Trends in exceedances of the ozone air quality standard in the continental United States, 1980-1998, Atmos. Environ., 35, 3217-3228, 2001.

Liu, S., Mo, X., Lin, Z., Xu, Y., Ji, J., Wen, G., and Richey, J.: Crop yield responses to climate change in the Huang-Huai-Hai Plain of China, Agr. Water Manage., 97, 1195-1209, 2010.

LRTAP Convention: Manual on Methodologies and Criteria for Modelling and Mapping Critical Loads and Levels and Air Pollution Effects, Risks and Trends, International Cooperative Programme on Mapping and Modelling under the UNECE Convention on Long-Range-Transboundary Air Pollution, 2004.

Mills, G., Buse, A., Gimeno, B., Bermejo, V., Holland, M., Ember- 
son, L., and Pleijel, H.: A synthesis of AOT40-based response functions and critical levels of ozone for agricultural and horticultural crops, Atmos. Environ., 41, 2630-2643, 2007.

Mills, G., Hayes, F., Simpson, D., Emberson, L., Norris, D., Harmens, H., and Buker, P.: Evidence of widespread effects of ozone on crops and (semi-)natural vegetation in Europe (1990-2006) in relation to AOT40-and flux-based risk maps, Global Change Biol., 17, 592-613, doi:10.1111/j.13652486.2010.02217.x, 2011a.

Mills, G., Pleijel, H., Braun, S., Buker, P., Bermejo, V., Calvo, E., Danielsson, H., Emberson, L., Fernandez, I., Grunhage, L., Harmens, H., Hayes, F., Karlsson, P., and Simpson, D.: New stomatal flux-based critical levels for ozone effects on vegetation, Atmos. Environ., 45, 5064-5068, doi:10.1016/j.atmosenv.2011.06.009, 2011b.

Monfreda, C., Ramankutty, N., and Foley, J. A.: Farming the planet: 2. Geographic distribution of crop areas, yields, physiological types, and net primary production in the year 2000, Global Biogeochem. Cy., 22, GB1022, doi:10.1029/2007GB002947, 2008.

Parrish, D. D., Aikin, K. C., Oltmans, S. J., Johnson, B. J., Ives, M., and Sweeny, C.: Impact of transported background ozone inflow on summertime air quality in a California ozone exceedance area, Atmos. Chem. Phys., 10, 10093-10109, doi:10.5194/acp10-10093-2010, 2010.

Pleijel, H., Danielsson, H., Ojanpera, K., De Temmerman, L., Hogy, P., Badiani, M., and Karlsson, P. E.: Relationships between ozone exposure and yield loss in European wheat and potato a comparison of concentration- and flux-based exposure indices, Atmos. Environ., 38, 2259-2269, 2004.

Prather, M., Ehhalt, D., Dentener, F., Derwent, R., Dlugokencky, E., Holland, E., Isaksen, I., Katima, J., Kirchhoff, V., Matson, P., Midgley, P., and M., W.: Climate Change 2001: The Scientific Basis, chap. Atmospheric chemistry and greehouse gases, Cambridge University Press, New York, USA, 239-287, 2001.

Roy, S. D., Beig, G., and Ghude, S. D.: Exposure-plant response of ambient ozone over the tropical Indian region, Atmos. Chem. Phys., 9, 5253-5260, doi:10.5194/acp-9-5253-2009, 2009.

Sacks, W. J., Deryng, D., Foley, J. A., and Ramankutty, N.: Crop planting dates: an analysis of global patterns, Global Ecol. Biogeogr., 19, 607-620, doi:10.1111/j.1466-8238.2010.00551, 2010.

Sitch, S., Cox, P. M., Collins, W. J., and Huntingford, C.: Indirect radiative forcing of climate change through ozone effects on the land-carbon sink, Nature, 448, 791-794, 2007.

Soldberg, S. and Lindskog, A.: The Development of European Surface Ozone. Implications for a Revised Abatement Policy, EMEP/CCC-Report 1, 2005.

Stockwell, D. Z. and Chipperfield, M. P.: A tropospheric chemicaltransport model: Development and validation of the model transport schemes, Q. J. Roy. Meteorol. Soc., 125, 1747-1783, 1999.

Stockwell, D. Z., Giannakopoulos, C., Plantevin, P. H., Carver, G. D., Chipperfield, M. P., Law, K. S., Pyle, J. A., Shallcross, D. E., and Wang, K. Y.: Modelling $\mathrm{NO}_{\mathrm{x}}$ from lightning and its impact on global chemical fields, Atmos. Environ., 33, 44774493, 1999.

Stohl, A.: A 1-year Lagrangian "climatology" of airstreams in the Northern Hemisphere troposphere and lowermost stratosphere, J. Geophys. Res.-Atmos., 106, 7263-7279, 2001.
Tong, D. Q., Mathur, R., Kang, D. W., Yu, S. C., Schere, K. L., and Pouliot, G.: Vegetation exposure to ozone over the continental United States: Assessment of exposure indices by the EtaCMAQ air quality forecast model, Atmos. Environ., 43, 724733, 2009a.

Tong, D. Q., Muller, N. Z., Kan, H. D., and Mendelsohn, R. O.: Using air quality modeling to study source-receptor relationships between nitrogen oxides emissions and ozone exposures over the United States, Environ. Int., 35, 1109-1117, 2009 b.

Tuovinen, J. P., Simpson, D., Emberson, L., Ashmore, M., and Gerosa, G.: Robustness of modelled ozone exposures and doses, Environ. Pollut., 146, 578-586, 2007.

USEPA: Air Quality Criteria for Ozone and Other Photochemical Oxidants, Vol. II. EPA-600/P-93/00bF, US Environmental Protection Agency, National Center for Environmental Assessment, US Environmental Protection Agency, National Center for Environmental Assessment, Research Triangle Park, NC, USA, 1996.

USEPA: National Ambient Air Quality Standards for Ozone: Proposed Rules, Federal Register, 75(11), available online at: http: //www.epa.gov/air/ozonepollution/fr/20100119.pdf, last access: 25 July, 2010a.

USEPA: Ozone Air Quality Standards, http://www.epa.gov/air/ ozonepollution/standards.html, access: 25 July, 2010b.

van der Werf, G. R., Randerson, J. T., Giglio, L., Collatz, G. J., Kasibhatla, P. S., and Arellano, Jr., A. F.: Interannual variability in global biomass burning emissions from 1997 to 2004, Atmos. Chem. Phys., 6, 3423-3441, doi:10.5194/acp-6-3423-2006, 2006.

Van Dingenen, R., Dentener, F. J., Raes, F., Krol, M. C., Emberson, L., and Cofala, J.: The global impact of ozone on agricultural crop yields under current and future air quality legislation, Atmos. Environ., 43, 604-618, 2009.

Wang, X. P. and Mauzerall, D. L.: Characterizing distributions of surface ozone and its impact on grain production in China, Japan and South Korea: 1990 and 2020, Atmos. Environ., 38, 43834402, 2004.

WHO: Air Quality Guidelines for Europe, Reg. Publ. Eur. Ser., WHO Reg. Off. Eur., Copenhagen, 2nd ed., 91, 288 pp., 2000.

Wild, O., Pochanart, P., and Akimoto, H.: Trans-Eurasian transport of ozone and its precursors, Journal of Geophys. Res.-Atmos., 109, D11302, doi:10.1029/2003JD004501, 2004.

Wild, O., Fiore, A. M., Shindell, D. T., Doherty, R. M., Collins, W. J., Dentener, F. J., Schultz, M. G., Gong, S., MacKenzie, I. A., Zeng, G., Hess, P., Duncan, B. N., Bergmann, D. J., Szopa, S., Jonson, J. E., Keating, T. J., and Zuber, A.: Modelling future changes in surface ozone: a parameterized approach, Atmos. Chem. Phys. Discuss., 11, 27547-27590, doi:10.5194/acpd-1127547-2011, 2011.

Zhang, Q., Streets, D. G., Carmichael, G. R., He, K. B., Huo, H., Kannari, A., Klimont, Z., Park, I. S., Reddy, S., Fu, J. S., Chen, D., Duan, L., Lei, Y., Wang, L. T., and Yao, Z. L.: Asian emissions in 2006 for the NASA INTEX-B mission, Atmos. Chem. Phys., 9, 5131-5153, doi:10.5194/acp-9-5131-2009, 2009.

Zhao, C., Wang, Y. H., Yang, Q., Fu, R., Cunnold, D., and Choi, Y.: Impact of East Asian summer monsoon on the air quality over China: View from space, Journal Of Geophys. Res.-Atmos., 115, D09 301, doi:10.1029/2009JD012745, 2010. 